\title{
Örgüt Kültürü: Kavramsal Çerçevesi ve Eğitim Yönetimi Açısından Değerlendirilmesi
}

\author{
Yrd. Doç. Dr. Ahmet AVCI* \\ Fatih Sultan Mehmet Vakıf Üniversitesi, Eğitim Fakültesi, Eğitim Bilimleri Bölümü, \\ Üsküdar / İstanbul / Türkiye
}

\section{$\ddot{\mathbf{O} z}$}

Örgüt kültürünün kurumlar için çok önemli bir yeri ve kurumların başarılı olabilmelerinde kritik bir rolü bulunmaktadır. Kurumların sahip oldukları örgüt kültürü; çalışma ortamını şekillendirmekte, çalışanların iş yapma biçimlerini ve kapasitelerini direkt olarak etkilemektedir. Kurumdaki insan kaynağının psikolojisi, motivasyonu, işini sahiplenme durumu ve verimlilik kapasitesi kurumdaki örgüt kültürüne göre yapılanmaktadır. Bu durum eğitim örgütleri için de aynıdır. Genel anlamda örgüt kültürü, örgüt içindeki bireyler ve gruplar tarafindan kabul edilen, paylaşılan ve uyulan normlar, kurallar, algılamalar ve değerler bütünü olarak ifade edilmektedir. Bir kurumun örgüt kültürü, kurumun ilkeler, inançlar ve değerler sistemidir. En genel anlamda eğitim yönetimi; eğitimsel hedef ve amaçlara, başarı ve verimlilikle ulaşmak adına eğitim ve yönetim bilimlerinin birlikte çalışma süreci olarak değerlendirilebilir. Etkili bir eğitim yönetimi için gerekli ortamın oluşturulmasında, eğitim ve öğretim hedeflerinin yerine getirilebilmesinde, başarılı ve mutlu öğrencilerin yetiştirilebilmesinde örgüt kültürü kritik bir öneme sahiptir. Örgüt kültürü, okul müdürlerinin liderlik ve yönetim tarzları başta olmak üzere kurumdaki yönetim süreçlerini etkilemekte aynı zamanda bu yönetim süreçlerinden de etkilenmektedir. Bu araştırmada,

* Sorumlu Yazar. Tel: +902125827090

E-posta:ahmetavci7@ gmail.com

(C) 2018 Kalem Eğitim ve Sağlık Hizmetleri Vakfı. Bütün Hakları Saklıdır. ISSN: 2146-5606 
okullardaki örgüt kültürünün kritik rolünden hareketle, örgüt kültürünün kavramsal çerçevesi ile örgüt kültürü ve eğitim yönetimi ilişkisi analiz edilecektir. Bu analizde, örgüt kültürünün eğitim yönetimine etkisi, bu etki neticesinde eğitim yönetiminin çıktıları incelenecek, bazı çıkarım ve önerilerde bulunulacaktır.

Anahtar Kelimeler: Örgüt kültürü; Eğitim yönetimi; Okul kültürü; Yönetim; Örgütsel davranış.

\title{
Organizational Culture: Conceptual Framework and Evaluation in Terms of Educational Administration
}

\begin{abstract}
Organizational culture is very important for institutions and has a critical role for institutions to be successful. The organizational culture of institutions forms the working environment and directly affects employees' way of doing business and their capacities. The psychology, motivation, job ownership status and productivity capacity of the human resource in the institution are organized according to the organizational culture in the institution. This is also the same for educational organizations. In the general sense, organizational culture is expressed as the whole of norms, rules, perceptions and values that are accepted, followed and shared by individuals and groups within the organization. Organizational culture of an institution is the system of principles, beliefs and values of the institution. Organizational culture has a critical importance in establishing the necessary environment for an effective educational administration, in achieving education and training objectives and in training successful and happy students. Organizational culture affects the management processes in the institution, especially the leadership and management styles of the school principals, and it is also affected by these management processes. In this research, the relationship between organizational culture and educational administration will be analyzed along with the conceptual framework of organizational culture based on the critical role of organizational culture in schools. In this analysis, the effect of organization culture on educational administration and the outcomes of educational administration as a result of this effect will be examined, and some deductions and suggestions will be made.
\end{abstract}

Keywords: Organizational culture; Educational management; School culture; Management; Organizational behavior. 


\section{Extended Summary}

\section{Purpose}

The purpose of this research is to examine the conceptual framework of organizational culture and to evaluate it in terms of educational administration. By this research, the conceptual framework of organizational culture was examined and the relationships between organizational culture and educational administration and organizational behavior were revealed. This research is important in terms of explaining the relationship between the strong organizational culture and educational administration for the presentation of the relationship between the structure of organizational culture felt in schools and educational administration and for the establishment of a healthy school administration and an effective education and training system.

\section{Method}

This research was carried out in qualitative form in the survey model and is a descriptive research in the documentary survey design in terms of data collection technique. In this research, primary data and resources were achieved by performing detailed literature and literature review. The conclusion part was created by performing the necessary examination, analysis and discussions on the collected data in accordance with the purpose of the research, and theoretical and practical suggestions were put forward.

\section{Results}

Organizational culture is also a very important concept for educational institutions, in particular for all institutions. Organizational culture plays a critical role in institutions' efforts to achieve their objectives and to succeed or fail. To analyze the conceptual framework of such an important factor and to reveal the relationship between the factors with which it interacts are quite important for the success of institutions.

As it is understood from the studies carried out in the field of theory and practice, there are significant relationships between many issues regarding the field of educational administration, in particular leadership, school climate, effective school, learning school, organizational citizenship behaviors, organizational trust, organizational commitment, organizational cynicism and student success that are among the most basic subjects of educational administration, and school culture. 
Positive and strong school culture positively affects the implementation of education and training in a healthy and successful manner, the leadership, the working environment in the school, employees in terms of liking the school and students, fulfilling their duties with the sense of trust and commitment and making extra efforts, and student success.

\section{Discussion}

The presence of a strong organizational culture in educational institutions is extremely important for education and training achieve their objectives, in other words for healthy administration of education and achieving successful results (Hallinger and Leithwood, 1996). In schools where there is a strong organizational culture, human resource is cared and valued, institutional support is provided for all employees in the organization (Carpenter, 2015), there is a positive and constructive communication environment, problem-solving capacity is high and tolerance comes into question in conflicts (Buch and Rivers, 2001). In these types of schools, there is a positive approach to change and innovation along with a strong, positive and fair administration (Berry, 1997), there is an institutional identity that is accepted and adopted by employees (Gagliardi, 1986), and employees believe in their institution and are happy to work in the institution (McMaster, 2015). In these types of schools, people act in unity and solidarity (Valimaa, 1998), employees try to be more beneficial to their institution by making an extra effort (Bogler and Somech, 2005) and avoid any attitude and behavior that may harm their institution (Beijaard, Verloop and Vermunt, 2000). In these types of institutions, lessons are taught usefully, the target achievements of the topics are achieved most successfully as there is a healthy school climate and a productive education and training environment (Griffith, 1999), and students grow up with high self-confidence (Gruenert, 2005) in line with individual differences (Gaziel, 1997).

Every organizational culture has an effect on the success of that organization and its members, and also school culture has a significant effect on the success of the education and training in the school. According to Yeşilyurt (2009), the success of a school is composed of the successes of all individuals in that school. In this sense, the success of schools is closely related to the teaching success of teachers working those schools. Therefore, it is clear that the unique culture of schools will have an effect on the success of all members of the school. Based on the positive and strong organizational culture in the 
school, positive attitudes of teachers and administrators towards each other, the presence of justice in the distribution of tasks and humanistic approach between teacher and administrators, and the fact that school members are open to change and innovation positively affect the teaching successes of teachers.

\section{Conclusion}

There is a significant relationship between a strong organizational culture, the structuring of a successful educational administration and obtaining positive outcomes. Based on this finding, necessary studies should be performed to increase positive and strong organizational culture in schools and this issue should be particularly emphasized. At this point, it is necessary to carry out researches about how to establish positive and strong organizational culture in schools and how to ensure the continuity of this with a sustainable structure from the highest level of educational administration to the lowest administration unit. The establishment of a strong organizational culture in schools and the fact that it has a sustainable structure are largely, closely associated with the success of the school administration. At this point, especially school principals should be aware of this critical role they have and should structure their administration by being conscious of it. In this context, they should give importance to knowledge and experience sharing by holding meetings on a district basis and should provide the necessary administrative support by following schools personally.

It is seen that important researches have been carried out on the school culture in the field of educational administration. It draws the attention that these researches are usually carried out in parallel with the main stream studies. At this point, it is necessary to carry out more qualitative and ethnographic studies on school culture and also researches that will reveal the relationship between school culture and educational reform.

\section{Giriş}

Örgüt kültürünün kurumlar için çok önemli bir yeri ve kurumların başarılı olabilmelerinde kritik bir rolü bulunmaktadır (Hofstede, 1998, 2011). Bundan dolayıdır ki örgüt kültürüne olan ilgi son dönemlerde ciddi anlamda artış göstermiştir. Örgüt kültürü ve ilişkili olduğu kavramlarla ilgili pek çok çalışma ve araştırma yapılmıştır (Schein, 2004; Schneider, Ehrhart ve Macey, 2013; Wilkins ve Ouchi, 1983). Örgüt kültürü, yönetim ve örgütsel davranış 
konularının neredeyse tamamıyla karş1lıklı bir etkileşime sahiptir. Örgüt kültürü bu kavramları hem etkilemekte, hem de bu kavramlardan etkilenmektedir (Schein, 1996; Schneider, 1988).

Bütün kurumlarda olduğu gibi eğitim kurumlarında da örgüt kültürüyle ilgili çalışmalar son dönemlerde artış göstermiştir. Yapılan birçok çalışmada; etkili bir eğitim ve öğretim için gerekli ortamın oluşturulmasında (Aidla ve Vadi, 2007), eğitim ve öğretim hedeflerinin yerine getirilebilmesinde, başarılı ve mutlu öğrencilerin yetiştirilebilmesinde örgüt kültürünün kritik bir öneme sahip olduğu vurgulanmıştır (Carpenter, 2015; Dumay, 2009).

$\mathrm{Bu}$ araştırmada, okullardaki örgüt kültürünün kritik rolünden hareketle, örgüt kültürünün kavramsal çerçevesi ile örgüt kültürü ve eğitim yönetimi ilişkisi analiz edilecektir. Bu analizde, örgüt kültürünün eğitim yönetimine etkisi ve bu etki neticesinde eğitim yönetiminin çıktıları incelenecektir. Örgüt kültürü, okul müdürlerinin liderlik ve yönetim tarzları başta olmak üzere (Deal ve Peterson, 1990), kurumdaki yönetim süreçlerini etkilemekte aynı zamanda bu yönetim süreçlerinden de etkilenmektedir (Dimmock ve Walker, 1997; Hallinger ve Leithwood, 1996). Bununla birlikte örgüt kültürü; örgütsel adalet, güven, bağl1lık (Shaw ve Reyes, 1992), vatandaşlık davranışları (DiPaola ve Tschannen-Moran, 2001), sinizm (Abraham, 2000) ve performans (Hanushek, 1997) olmak üzere birçok örgütsel davranış ve eğitim yönetimi (Stolp ve Smith, 1995; Yolcu, 2016) konularıyla direkt veya dolaylı olarak etkileşim halindedir.

\section{Kavramsal Çerçeve}

\section{Örgüt Kültürü}

Kurumların varlıklarını sürdürebilmelerinin temelinde, etkinliğini artırma ve rekabet gücünü koruyabilme özellikleri vardır. İlk dönemlerde, işletmelerin bunu başarabilmelerinde teknik üstünlüklerinin ve üretim miktarlarının etkisinin büyük olduğu düşünülmekteydi. Bu noktada kurumlar bir dizi mekanik sistemden ibaret görülmekteydi. Bu bağlamda kurumlardaki insan kaynağı da bu mekanik sistemin bir parçası olarak algılanmaktaydı (Robbins ve Judge, 2012). Ancak daha sonraları, kurumların başarılarındaki asıl etkenin kurumların sahip oldukları insan kaynağı ve bu insan kaynağına verilen değer çerçevesinde oluştuğu anlaşıldı (Robbins, Decenzo ve Coulter, 2013). Nitekim yapılan birçok çalışmada, örgütteki insan kaynağının sahip olduğu niteliklerin, yönetim biçiminin, örgütsel bağlılığın, güvenin ve vatandaşlığın; 
kurumsal etkililik, verimlilik ve başarıda temel etkenler olduğu ortaya konulmuştur (Drucker, 2011; Lok ve Crawford, 1999). Bu noktada; işletmenin sahip olduğu örgüt kültürünün kritik rolü, karşımıza çıkmaktadır. Kurumdaki örgüt kültürü, kurumların sahip oldukları insan kaynağının yapısını, olumlu veya olumsuz yöndeki değişimini direkt olarak etkilemektedir. Bütün bunların neticesinde, kurumlardaki örgüt kültürünün, kurumun başarı veya başarısızlığında birinci derecede etken olduğu ortaya çıkmaktadır (Cameron ve Sarah, 1991; Lim, 1995).

Örgüt kültürünün birçok tanımı olmakla birlikte, üzerinde uzlaşmaya varılmış net bir tanımı bulunmamaktadır (Allaire ve Firsirotu, 1984). Genel anlamda örgüt kültürü, örgüt içindeki bireyler ve gruplar tarafindan kabul edilen, paylaşılan ve uyulan normlar, kurallar, algılamalar ve değerler bütünü olarak ifade edilmektedir (Deshpande ve Webster, 1989; Pettigrew, 1979). Bir kurumun örgüt kültürü, kurumun ilkeler, inançlar ve değerler sistemidir (Smircich, 1983). Alanyazında çok farklı şekilde ifade edilmiş örgüt kültürü tanımlarından hareketle, örgüt kültürünü; örgütteki bireylerin kabul ettikleri, inandıkları ve paylaştıkları, bireylerin düşünce, duygu, tutum ve davranışlarını şekillendiren, örgütü karakterize eden ve diğer örgütlerden ayıran, örgütün iç ve diş ilişki ve iletişimini şekillendiren, yön veren, bunlarla uyumunu sağlayan, örgüt içerisinde birlik ve beraberliği temin eden, bireylerin iş yapma yöntemini belirleyen ve bireyler arasında nakledilen inançlar, değerler, davranışlar ve alışkanlıklardan oluşan temel sayıltılar, hikâyeler, mitler, semboller ve uygulamaların toplamı şeklinde tanımlamak mümkündür (Avc1, 2016).

Örgüt kültürü kavramının ilk kullanımı, tanımlanması, yapısı ve gelişimiyle ilgili de farklı fikirler ortaya konulmaktadır. Hofstede (2011) örgüt kültürü kavramının ilk kullanımını Jaques'e (1951), ilk tanımlanmasını ise Pettigrew'e (1979) atfetmektedir. Bununla birlikte, Pettigrew'den (1979) yaklaşık yedi y1l önce, Harrison'un (1972) Harvard Business Reveiw'de yayımlanan "Understanding Your Organization's Character" isimli makalesinde örgütün yapıs1, değerleri, ideolojileri, örgütün güç, rol, görev veya birey yönelimli oluşu tartışılmaktadır. Aslında Harrison (1972), burada örgüt kültürünü tanımlamaktadır. Aynı şekilde, Wilkins ve Ouchi'nin (1983), Conklin (1968) ve Goffman'a (1971); Smircich'in (1983), Pepper (1942), Kaplan (1964), Turner (1971) ve Brown'a (1977); Schneider'in (1988), Hall (1960), Kluckholn ve Strodtbeck (1961) ile Wallin'e (1972); Hofstede'in (1998) Kuhn (1970), Rokeach (1972) ve Levitin'e (1973) atıfla yaptıkları açıklama 
ve tanımlar aslında örgüt kültürü konseptini ve bileşenlerini ifade eden açıklamalardır. Dolayısıyla bunlar referans alındığında örgüt kültürü kavramını 1940'lara hatta daha erken zamanlara götürmek mümkündür. Nitekim Hoy ve Miskel (2010), iş yerlerinin ve iş-çalışma gruplarının kültürüne olan ilginin yeni olmadığını ifade etmekte; 1930'larda ve 1940'larda hem Mayo (1945) hem de Barnard'ın (1938) informel örgütün doğasını ve işlevini tanımlarken, işyerinde insanlar arası etkileşimlerde ortaya çıkan duyguların, değerlerin ve grup normlarının önemini vurguladığını ifade etmektedir. Aynı şekilde, Selznick'in (1957) de örgütsel yaşama ilişkin çözümlemelerinde, örgütleri, rasyonel örgütler-sistemler olmaktan çok kurum kültürü olan yapılar olarak görmek suretiyle analizlerini yaptığını belirtmektedir (Hoy ve Miskel, 2010). Ancak bütün bu değerlendirmelerle birlikte konuyu, Hofstede'in (2011) örgüt kültürü kavramının ilk kullanımını Jaques'e (1951), ilk tanımlanmasını ise Pettigrew'e (1979) atfetmesi meseleyi belli noktada çözüme kavuşturmaktadir. Deal ve Kennedy'nin (1982) "Corporate Cultures"; Schein'in (1984) “Organizational Culture and Leadership"; Peters ve Waterman'in (1984) "In Search of Excellence"; isimli kitapları ile Harrison'un (1972) "Understanding Your Organization's Character"; Pettigrew'in (1979) "On Studying Organizational Cultures"; Smircich'in (1983) "Concepts of Culture and Organizatinol Analysis"; Wilkins ve Ouchi'nin (1983) "Efficent Cultures: Exploring the Relationship Between Culture and Organizational Performance"; Schneider'in (1988) "National vs. Corporate Culture: Implications for Human Resource Management"; Hofstede'in (1998) "Attitudes, Values and Organizational Culture: Disentangling the Concepts"; isimli makaleleri, örgüt kültürü kavramının yapısı ve gelişimiyle ilgili olarak önemli bilgileri ihtiva etmekte ve alana 1şık tutmaktadır.

Örgüt kültürü, örgütteki varsayım ve ideolojileri yansıtır. Örgüt kültürünün, örgütü karakterize eden bir yapısı vardır. Örgüt kültürü birçok bileşenden meydana gelmektedir (Barley, 1983). Örgüt kültürü kurumdaki yönetim biçimini, alınacak kararları, yapılacak tercihleri ve uygulama stratejilerinin belirlenmesini de önemli ölçüde etkilemektedir (Gagliardi, 1986; Meek, 1988). Robbins ve Judge'a (2012) göre, güçlü örgüt kültürünün bulunduğu kurumlarda, örgütlerin öz değerleri hem yoğun şekilde sahiplenilir hem de yaygın şekilde paylaş1lır. Örgüt üyeleri öz değerleri hangi yoğunlukta kabullenir ve onlara bağl1lık gösterirse, örgüt kültürü de çalışanların davranışlarını o yoğunlukta etkiler ve şekillendirir. 
Güçlü örgüt kültürüne sahip bir kurumda, herkes aynı ilkeleri, inançları ve değerleri bilir ve onları destekler (Wiener, 1988). Kurumların sahip oldukları örgüt kültürü, çalışma ortamını şekillendirmekte, çalışanların iş yapma biçimlerini ve kapasitelerini direkt olarak etkilemektedir (Schein, 1990). Kurumdaki insan kaynağının psikolojisi, motivasyonu, işini sahiplenme durumu ve verimlilik kapasitesi kurumdaki örgüt kültürüne göre yapılanmaktadır (Drucker, 1988). Kurumların hedefleri doğrultusunda vizyon ve misyonlarıla uyumlu olarak değişim ve gelişime adapte olabilmesi (Schneider, 1988); ürün ve hizmetlerinde istikrarlı bir başarı grafiği çizebilmesi (Deshpande ve Webster, 1989); sağlıklı bir yönetim ve liderlik sistemi geliştirebilmesi (Bass ve Avolio, 1993; Tucker ve Russell, 2004) çalışanların kurumlarına karşı güven ve bağlılık duyabilmesi, çalışanlar arasında ahenk, uyum, birlik ve beraberliğin tesis edildiği bir atmosferin oluşturulmasında örgüt kültürünün çok önemli bir yeri bulunmaktadır (Schein, 1990; Hofstede, Neuijen, Ohavy ve Sanders, 1990).

Bütün bunlarla birlikte güçlü örgüt kültürü, örgütün temsil ettiği değerler hakkında yüksek düzeyde ittifak ya da amaç birliği sağladığı için çalışan devir oranını da azaltacaktır. Böylesi bir ittifak; örgütte uyumun, sadakatin ve örgütsel bağlılı̆̆ın oluşmasını sağlayacaktır. Bu özellikler, hem çalışanların işten ayrılma eğilimlerini azaltacak hem de verimliliği ciddi oranda artıracaktır (Robbins ve Judge, 2012). Boone ve Kurtz'a (2013) göre, örgüt kültürü çok güçlü ve sürekli olabilir, ancak bazen iş çevrelerindeki yeni talepleri karşılamak için değişime zorlanır. Geleneğe ve bürokrasiye çakılı kalmış bir kurum, teknolojide ve müşteri tercihlerindeki değişimlere yanıt vermek amacıyla daha yalın, daha esnek bir kültüre doğru değişmek zorunda kalabilir.

Bütün örgütler gibi okul da çok amaçlıdır. Okulun amacı sadece eğitim ve öğretim değildir (Bursalığlu, 2010a). Bu bağlamda, okuldaki kültürü iyi tanımak ve anlamak eğitim ve öğretimin amaçlarını tam olarak yerine getirmek, verimliliği artırmak ve okulun toplumla doğru şekilde entegrasyonu açısından son derece önemlidir. Eğitim kurumlarındaki örgüt kültürünün (okul kültürünün) kapsam ve yapısı, diğer kurumlardakilerle birçok noktadan benzerlik göstermektedir (Dumay, 2009). Okul çeşitli değerlerin bir arada bulunduğu ve çatıştığ 1 bir örgüttür. Okulun temel görevlerinden biri, hem kendi içinde hem de kendi dışında çatışan sosyal, politik ve ekonomik değerleri uzlaştırmak ve dengelemektir. Okulu sadece bir öğrenim kurumu 
olarak görmek, değerler arasındaki çatışmayı daha da artıracaktır (Çelik, 2009, 2013). Ancak bütün bunlarla birlikte, okul dediğimiz örgütün en önemli ve açık özelliği, üzerinde çalıştığı hammaddenin toplumdan gelen ve topluma giden insan oluşudur. Bu noktada, okulun birey boyutu kurum boyutundan daha duyarlı; informel yanı, formel yanından daha ağır; etki alanı yetki alanından daha geniştir. Gerçekten sosyal bir sistem olarak kurulması ve çalışması gereken okul ortamında, davranış bilimleri ve insan ilişkilerinin yeri bu bakımdan büyük önem taşımaktadır (Bursalığlu, 2010b).

Okul kültürü, farklı bakış açılarına göre birçok şekilde tanımlanmıştır (Gruenert, 2005). Stolp ve Smith'e (1995) göre kültürün en önemli özelliklerinden birisi durağan değil de aktif oluşudur. Bundan dolayıdır ki, değişim içinde bulunan okul kültürü kavramını tek bir bakış açısı ve tanımla açıklamak mümkün değildir. Terzi (2005) de okul kültürü teriminin sıklıkla iklim kavramıyla eşanlamlı bir şekilde kullanıldığından bahsederek, eğitim bilimleri alanında okul kültürünün açık ve tutarlı bir tanımının bulunmadığını belirtmektedir. En genel anlamda okul kültürü; yönetici, öğretmen ve çalışanlar tarafindan paylaşılan normlar, inançlar, değerler ve varsayımlardan oluşan bir yapıdır (Deal ve Peterson, 1990). Stolp ve Smith (1995) okul kültürünü, bir okulu diğerlerinden ayıran, onu tek kılan, özellikler, algılamalar ve varsayımlar bütünü olarak tarif etmektedir. Hackman (1993) de okul kültürünü, öğrenciler, öğretmenler ve idarecilerin yaygın şekilde sahip oldukları inançlar, değerler ve varsayımlar olarak ifade etmektedir. Alanyazında çok farklı şekilde ifade edilmiş okul kültürü tanımlarından hareketle, okul kültürünü; okuldaki yönetici, öğretmen, öğrenci ve çalışanların kabul ettikleri, inandıkları ve paylaştıkları; okuldaki bütün bireylerin düşünce, duygu, tutum ve davranışlarını şekillendiren; okulu karakterize eden ve diğer okullardan ay1ran; okulun iç ve dış ilişki ve iletişimini şekillendiren, yön veren, bunlarla uyumunu sağlayan, okul içerisinde birlik ve beraberliği temin eden; yönetici ve öğretmenlerin iş yapma yöntemini belirleyen, çalışanlar arasında nakledilen ve öğrenciler tarafından paylaşılan inançlar, değerler, davranışlar ve alışkanlıklardan oluşan temel sayıltılar, hikâyeler, mitler, semboller ve uygulamaların toplamı şeklinde tanımlamak mümkündür (Avc1, 2016).

Örgüt kültürü, planlanabilir, eşgüdümlenebilir, denetlenebilir ve değiştirilebilir bir özellik taşır. Diğer bir ifadeyle örgüt kültürü yönetilebilir. Örgüt kültürünün bilinçli olarak oluşturulması, korunması, tanıtılması ve değiştirilmesi, örgüt kültürünün yönetimini, eğitim ve okul yönetiminin güncel bir 
alanı haline getirmiştir (Çelik, 2009). Negiş-Işık ve Gürsel (2013) yaptıkları araştırma neticesinde, okul kültürünün ön plana çıkan özelliklerini; 1) Farklı görüşlere sahip öğretmenlerin olumlu ilişkiler ortaya koyabilmesi, 2) Problemlerin çözümünde ortak tavır sergilenmesi, 3) Okul yöneticisinin başarılı liderlik davranışları sergilemesi olarak tespit etmiştir.

Deal ve Peterson'in (1990) “The principal's role in shaping school culture" isimli çalışması; okul yöneticilerinin, okul kültürünün yapılandırılmasına olan etkisini analiz etmesi ve okul kültürüyle okul başarısı arasındaki ilişkiyi ortaya koyması bakımından oldukça önemlidir. Okul yöneticisi, diğer yönetsel etkinliklerle birlikte okul kültürünü bilinçli ya da bilinçsiz olarak yönetmektedir. Okul kültürünün gücünü ve yönetim süreçleri açısından önemini iyi bilen okul yöneticisi, daha başarılı bir kültür yönetimi davranışı sergileyebilir. Bu noktada yöneticinin okul kültürünü yapılandırmadaki ilk görevi, güçlü bir okul kültürü oluşturmaktır. Güçlü okul kültürü de yönetici, öğretmen ve diğer çalışanların ortak değer, norm ve inançlar etrafında birleşmeleri sonucunda ortaya çıkmaktadır (Çelik, 2009, s.67).

Güçlü örgüt kültürü bulunan başarılı okullarda; disiplin ve şiddet sorunlarının olmadığ 1 sağliklı bir eğitim ve öğretim ortamı (Goldring, 2002), paylaşılan güçlü değerler, tüm öğrencilerin ve bireylerin başarılı olacağına dair kuvvetli bir inanç (Salfi ve Saeed, 2007), öğretmenlerin öğrencileri için olumlu rol-model olmaları (Ellett ve Tedlie, 2003), paylaşılan inançlar, değerler ve gelenekler, güçlü liderlik ve güçlü liderliğinin başarı için gerekliliğine olan sağlam bir inanç vardır (Aidla ve Vadi, 2007). Güçlü okul kültürü de yönetici, öğretmen, okuldaki tüm çalışanlar ile öğrenci ve velilerin de ortak inanç, değer, norm ve idealler etrafında birleşmeleri sonucunda ortaya çıkmaktadır (Lunenburg ve Ornstein, 2013; Stolp ve Smith, 1995).

\section{Eğitim Yönetimi}

Drucker'a (2012) göre yönetim evrensel bir kavramdır ve yönetim sözcügü yüzlerce y1llık bir geçmişe sahiptir. Yönetim, hem bir işlevi hem de o işlevi yerine getiren insanları ifade eder. Yönetim, bir sosyal konumu ve yetkiyi anlatır ama aynı zamanda bir bilim dalını ve öğrenim alanını da ifade eder. Tüm kurumlarda ortak bir yönetim işlevi, yönetim görevi ve yönetim çalışması vardır. Yönetim, hedeflere etkili ve verimli şekilde ulaşabilmek için yönetim fonksiyonlarının yerine getirilmesi şeklinde düşünülebilir (Drucker, 1988). Yönetim kavramı, bilim alanlarının yaklaşımlarına göre farklı şekillerde tanımlanmıştır. Yönetim en genel anlamda; insanlar ve diğer kaynaklar 
yoluyla örgütsel hedefleri başarma sürecidir. Yöneticinin işi ise insanı ve teknik kaynakları örgütün amaçlarını başarmak için mümkün olan en iyi tarzda birleştirmektir (Boone ve Kurtz, 2013). Robbins, Decenzo ve Coulter (2013) yönetimi; birtakım işleri başkaları aracıllğıyla etkin ve verimli bir şekilde yerine getirme süreci olarak tarif etmektedir. Buradaki süreç kavramı, birbiriyle bağlantılı ve süregelen bir dizi eylemi; verimlilik ise bir görevi en doğru şekilde, en az kaynakla ve en başarılı şekilde sonuçlandırmayı ifade etmektedir.

Fayol da yönetimin beş temel fonksiyonunun olduğunu belirterek; yönetim kavramının içerik ve süreçleri hakkında bilgi vermektedir (Hodgetts, 1997): 1) Planlama: Olayların önceden tahminini ve bu tahmine dayanarak bir faaliyet programının oluşturulmasını kapsamaktadır. 2) Örgütlendirme: Tayin edilen görevlerin başarılması için personel, materyaller ve aktivitelerin yapılandırılmasını gerektirir. Bu tüm işletmenin kaynaklarının etkin koordinasyonunu zorunlu kılmaktadır. 3) Yürütme: Liderlik sanatı ile organizasyonun belirlenen amacını birlikte harekete geçiren bir süreçtir. İyi bir örnek ortaya koymak, organizasyonun periyodik incelemesini yapmak, yeterli olmayan işgörenleri elemek, detaylarda boğulmamak. 4) Koordine etme: Örgütsel amaçların elde edilmesi için gerekli olan zorunlu birlik ve uyumu sağlar. 5) Kontrol etme: Her şeyin kabul edilmiş planla uygunluk içinde yapıldığını görmeyi gerektirir.

Şüphesiz ki ülkelerin gelişmeleri; bilimsel, teknolojik, ekonomik ve savunma alanları başta olmak üzere tüm alanlarda varlık gösterebilmeleri ancak başarılı bir eğitim sistemi ile mümkün olabilmektedir. Eğitim sisteminin de başarılı olabilmesi, eğitim süreçlerinin sağlıklı ve bilimsel veriler 1şığında yönetilebilmesi ile mümkündür (Örücü ve Şimşek, 2011). Bu noktada eğitim yönetimi bilim dalının önemi ve kritik rolü karşımıza çıkmaktadır. Hallinger ve Leithwood (1996), "Culture and Educational Administration" isimli makalede, özellikle son 15 yılda eğitim yönetimi alanına ilginin artt1ğını ve konuyla ilgili önemli çalışmaların yapıldığını belirtmektedir. Makalenin yayımlanma tarihinden günümüze kadar geçen sürede yapılan çalışmaları da dikkate aldığımızda yaklaşık son 35 yılda eğitim yönetimi alanıyla ilgili kuram ve uygulamada ciddi çalışmaların yapıldığı ortaya çıkmaktadır. Gelişen bilimsel, sosyal, politik ve siyasi süreçler eğitime ve eğitim yönetimine bakış açısını değiştirmiş; meydana gelen bu hızlı değişimlere uyum sağlayabilme noktasında, eğitim yönetimine önemli rol ve sorumluluklar 
yüklenmiştir (Dimmock ve Walker, 1997; Donmoyer, 1999; Scheurich, 1995; Willower ve Forsyth, 1999).

Eğitim yönetimi, yönetim biliminin bir dalı olup; yöneticilikle ilgili genel kavramlarını yönetim biliminden, özel kavramlarını ise kendi alanındaki yönetim uygulamalarından alır (Ilgar, 2005). En genel anlamda eğitim yönetimi; eğitimsel hedef ve amaçlara, başarı ve verimlilikle ulaşmak adına eğitim ve yönetim bilimlerinin birlikte çalışma süreci olarak değerlendirilebilir (Lunenburg ve Ornstein, 2013; Hoy ve Miskel, 2010). Eğitim yönetimi; eğitim örgütlerinin hedeflerine ulaşabilmeleri için insan kaynakları başta olmak üzere yönetim bileşenlerinin en etkili ve verimli bir biçimde kullanılmasını inceleyen bilim dalı olarak değerlendirilebilir (Evers, 2003; Maxcy, 2001). Başaran'a (1982) göre eğitim yönetimi; toplumun eğitim ihtiyaçlarını karşılamak üzere kurulan eğitim sisteminde millî eğitimin amaçlarını gerçekleştirebilmek için bir araya gelen eğitim personeli ile diğer kaynakları örgütlendirip eşgüdümleyerek eyleme geçirme sürecidir. Bursalığlu'na (2010a) göre eğitim yönetimi, eğitim ve yönetim bilimlerinin birlikte oluşturdukları disiplinler arası bir bilim dalı, kısaca yönetim biliminin eğitime uygulanması olarak tanımlanabilir. Bu anlamda eğitim yönetimi, kamu yönetiminin eğitim alanına uygulanmasıdır. Eğitim yönetimi, eğitim sisteminin amacını gerçekleştirebilmek için, eğitim örgütlerinde yer alan insan gücü, sermaye, zaman, malzeme ve yer unsurlarının daha verimli, daha ekonomik ve daha iyi bir biçimde kullanılabilmesi anlamına gelir. Taymaz (2009) da eğitim yönetimini; kamu yönetiminin özel bir alanı olduğunu belirterek, okul yönetimini de eğitim yönetiminin daha sınırlı bir alana uygulanması olduğunu ifade etmektedir. Sınıf yönetimi ise eğitim yönetimi, sıra dizinin ilk basamağıdır. Eğitim yönetiminin kalitesi, büyük ölçüde sınıf yönetiminin başarısına bağlıdır (Taymaz, 2009). Eğitim yönetiminde üretilen kuramsal ve uygulama bağlamındaki bilgi; yönetim ve kamu yönetiminde kullanılan yaklaşımlardan istifade edilerek geliştirilmiştir (Hoy ve Miskel, 2010).

Ülkelerin gelişmesi, teknolojik ve ekonomik anlamda bir güç olabilmesi noktasında eğitim yönetimi, kritik bir rol oynamaktadır (Macneil, Prater ve Busch, 2009). Çünkü, bir ülkede eğitim yönetimi ne kadar başarılı ise eğitimin hedeflerine ulaşma oranı ve eğitimden beklenen sonuçlar da o kadar başarılı olacaktır (Schoen ve Teddlie, 2008). 


\section{Örgüt Kültürü ve Eğitim Yönetimi}

Örgüt kültürü kurumdaki yönetim biçimini etkilemekte ve aynı zamanda kurumdaki yönetim tarzından da etkilenmektedir. Bu bağlamda kurumdaki örgüt kültürünün sahip olduğu nitelikler, kurumdaki yönetim tarzını ve netice itibariyle kurumsal başarıyı direkt olarak etkilemektedir (Ogbonna ve Harris, 2000; Schein, 2004). Bu durum eğitim kurumları için de aynen geçerlidir. Bu anlamda, örgüt kültürü ve eğitim yönetimi arasında önemli bir etkileşim mevcuttur (Carpenter, 2015; Pounder, Ogawa ve Adams, 1995; Şişman, 2007, 2012). Nitekim Hallinger ve Leithwood'un (1996) "Culture and educational administration"; O'Hanlon'un (1983) "Theory Z in school administration"; Stolp ve Smith'in (1995) "Transforming school culture"; Deal ve Kennedy'nin (1983) "Culture and school performance"; Goldring' in (2002) "The power of the school culture"; Owens' In (2001) "Organizational behavior in education: Instructional leadership and school reform"; Owens ve Steinhoff'un (1988) "Towards a theory of organizational culture"; Dumay'in (2009) "Origins and consequences of schools' organizational culture for student achievement" isimli çalışmalarında konu detaylı şekilde işlenmiş ve eğitim kurumlarının sahip olduğu örgüt kültürünün eğitimin yönetilmesinden, okul yöneticilerinin liderlik stillerine, öğretmenlerin görevlerini yerine getirme biçimlerinden, öğrencilerinin başarılı olmalarına kadar birçok konuya doğrudan etki ettiği ifade edilmiştir. Güçlü ve olumlu bir örgüt kültürünün bulunduğu okullarda, okul yönetiminin belirlenen hedeflere ulaşma konusunda daha başarılı olacağı; kurumda olumlu ve yapıcı bir iletişim ortamıyla birlikte (Griffith, 1999); adaletli, objektif ve şeffaf bir yönetim anlayışının bulunacağı ifade edilmektedir (Berry, 1997). Böyle bir okul ortamında öğretmenlerin de kurumlarına güven, bağl1lık ve aidiyet duygusuyla yaklaşaca$\breve{g} 1$, iş ve görevlerini yerine getirirken örgütsel vatandaşlık davranışları sergileyeceği (Bogler, 2001; Bogler ve Somech, 2005); öğrencileriyle daha fazla ilgileneceği ve öğrencilerinin başarıları için daha çok gayret sarf edecekleri belirtilmektedir (Burns ve Carpenter, 2008). Aynı zamanda böyle bir okul ortamında çalışan öğretmenlerin; kurum ve çalışanlarına karşı olumlu davranışlar sergileyeceği ve aleyhte tutum ve davranışlarda bulunmayacakları ifade edilmektedir (DiPaola ve Hoy, 2005).

Örgüt kültürü ve eğitim yönetimi ilişkisinde, güçlü örgüt kültürünün yönetime katkıları diğer bir açıdan şöyle özetlenebilir (Robbins ve Judge, 2012): 1) Üyelerine kimlik duygusu kazandırır. 2) Bireyin kişisel çıkarlarının ötesinde daha büyük bir olguya bağl1lı̆̆ının oluşmasını sağlar. 3) Sosyal 
sistemin istikrarını temin eder. 4) Çalışanların söylemeleri ve yapmaları gereken şeyler için uygun standartlar sağlayarak örgütü bir arada tutmaya yardımcı olan sosyal bir yapıştırıcı rolü üstlenir. 5) Çalışanların tutum ve davranışlarına yol gösteren ve onları şekillendiren bir kontrol mekanizma vazifesi görür.

Eğitim kurumlarındaki örgüt kültürü ile eğitim yönetimi ve paydaşlarıyla ilgili yerli ve yabancı pek çok çalışma yapılmıştır. Bu çalışmalarda örgüt kültürünün, eğitim yönetimi ve kurumsal başarı ile eğitim ve öğretim çıktılarının oluşmasındaki etkisi ortaya konulmuştur:

Kültür ve eğitim yönetimi (Hallinger ve Leithwood, 1996), okul kültüründe yeni bir model (Schoen ve Teddlie, 2008), etkili okullar (Edmonds, 1979), okul kültür ve ikliminin öğrenci başarısına etkisi (Macneil, Prater ve Busch, 2009), eğitim yönetimi (Hoy ve Miskel, 2010; Lunenburg ve Ornstein, 2013; Gedikoğlu, 1997), örgüt kültürü gücünün, örgütsel performansa etkisi (Bipath ve Adeyemo, 2014), öğrenci başarısında okuldaki kültürün kaynakları ve çıktıları (Dumay, 2009), eğitim yönetiminde iş değerleri ve örgüt kültürü (Karataş, 2009), vizyon ve okul kültürü (Pawlas, 1997), toplam kalitede liderlik ve örgüt kültürü (Buch ve Rivers, 2001), hizmetkar liderlik, örgüt kültürü ve öğrenci başarısı (Herndon, 2007), örgüt kültürü ve örgütsel vatandaşlık davranışı (İpek, 2012; Koşar ve Yalçınkaya, 2013), liderlik ve okul kültürü (Şahin, 2011a), okul kültürü ve kültürler arası karşılaştırma (Şahin, 2011b), örgüt kültürü ve eğitim yönetimi (Tierney, 1988), yönetsel etkililik (İra, 2011), öğrenci motivasyonu (Fyans ve Maehr, 1990), öğrenci başarıs1 (Gruenert, 2005; Hanushek, 1997; Salfi ve Saeed, 2007), performans (Aidla ve Vadi, 2007), bağl1lık (Bozoğlu, 2011; Sezgin, 2010), öğretmenlerin değer sistemleri (Firat, 2007), sinizm (Şirin, 2011), güven (Yüksel, 2009).

$\mathrm{Bu}$ araştırmanın amacı örgüt kültürünün kavramsal çerçevesinin incelenmesi ve eğitim yönetimi açısından değerlendirilmesidir. Bu araştırmayla örgüt kültürünün kavramsal çerçevesi incelenmiş, örgüt kültürü ile eğitim yönetimi ve örgütsel davranış konularının arasındaki ilişkiler ortaya konulmuştur. $\mathrm{Bu}$ araştırma, okullarda hissedilen örgüt kültürü yapısıyla eğitim yönetimi ilişkisinin ortaya konulması, sağlıklı bir okul yönetimi ile verimli bir eğitim ve öğretim sisteminin tesis edilmesi adına, güçlü örgüt kültürünün eğitim yönetimiyle ilişkisini ifade etmesi bakımından önemlidir. 


\section{Yöntem}

$\mathrm{Bu}$ araştırma, nitel (qualitative) türde, tarama (survey) modelinde, veri toplama tekniği açısından ise belgesel tarama (documentary survey) deseninde, betimsel bir araştırmadır. Betimsel araştırmalar, olay, olgu ve ilişkileri olduğu gibi araştırmaya, tanımlamaya ve açıklamaya çalışan araştırmalardır (Karasar, 2007). Nitel türdeki araştırmalar; olay, olgu ve ilişkilerin nasıl gerçekleştiği, anlaşıldığ 1 ve yorumlandığıyla ilgilenmesi bakımından temelde "yorumsal" bir bakış açısına dayanmaktadır. Nitel araştırma türünde araştırmacı, araştırma bağlamına uygun ve esnek veri toplama, analiz etme, çözümleme ve yorumlama yöntemlerini kullanır (Bakioğlu ve Kurnaz, 2011). Tarama modelleri ise geçmişte ya da halen var olan bir durumu olduğu şekilde betimlemeyi amaçlayan araştırma yaklaşımıdır. Tarama modelinde araştırmac1, var olan durum veya olguyu dikkatle betimlemeye ve konuyla ilgili önemli analizler yapmaya çalışır. Belgesel tarama modeli ise belli bir amaca dönük olarak, kaynakları bulma, inceleme, analiz etme ve yorumlama süreçlerini kapsamaktadır. Belgesel tarama türündeki araştırmalarda veriler, var olan kayıt, belge, araştırma sonuçları ve dokümanlardan elde edilir. Belgesel tarama türündeki araştırmalar, amaç yönünden, genel tarama ve içerik çözümlemesi (content analysis) olmak üzere iki gruba ayrılmaktadır (Karasar, 2007). Bu araştırmada, alanyazın taraması olarak bilinen genel tarama modeli kullanılmış ve betimsel analizler yapılmıştır. Başarılı bir belgesel taramanın temel koşulu, konuyla ilgili belgelerin bulunması, incelenmesi ve bir senteze varılabilmesi için gerekli düzenlemelerin yapılabilmesidir (Karasar, 2007). $\mathrm{Bu}$ araştırmada, detaylı alanyazın taraması yapılarak birincil veri ve kaynaklara ulaşılmıştır. Toplanan veriler üzerinde araştırmanın amacına uygun olarak gerekli inceleme, analiz ve tartışmalar yapılarak sonuç kısmı oluşturulmuş, kuramsal ve pratik yönden öneriler ortaya konulmuştur.

\section{Tartışma}

$\mathrm{Bu}$ araştırma, okullardaki örgüt kültürü algısının incelenmesi ve eğitim yönetimi açısından değerlendirilmesi amacıyla yapılmıştır. Okullardaki örgüt kültürü algısının tespitine yönelik yapılan araştırmalarda, örgüt kültürüyle ilgili olarak genellikle, olumlu yönde orta veya yüksek düzeyde bir algıya rastlanmıştır. Ada ve Ayık (2008), Arlı (2011), Arslan, Kuru ve Satıcı (2005), Arslan, Özer ve Bakır-Ağaoğlu (2009), Arslan, Satıcı ve Kuru (2007), Bozoğlu (2011), Atay (2001), Ayık ve Şayir (2015), Çetin-Ölçüm (1999), Demirkol ve Savaş (2012), Fırat (2007), Gün ve Çağlayan (2013), İra (2011), Kalkan (2013), Karataş (2009), Korkut ve Hacıfazlıoğlu (2011), Koşar ve 
Yalçınkaya (2013), Oğuz ve Yılmaz (2006), Yüksel (2009), Sönmez (2006), Şahin (2004, 2010), Şahin-Firat (2010), Şimşek ve Altınkurt (2010), Şirin (2011) ve Terzi'nin (2005) yaptı̆̆ 1 araştırmalarda, öğretmen algılarına göre okullardaki örgüt kültürü olumlu yönde ve çoğunlukla yüksek düzeyde, kısmi araştırma sonuçlarına göre ise orta düzeyde bir algıya rastlanmıştır.

Eğitim kurumlarında güçlü bir örgüt kültürünün bulunması, eğitim ve öğretimin hedeflerine ulaşması diğer bir ifadeyle eğitimin sağlıklı şekilde yönetilmesi ve başarılı sonuçlar elde edilmesi açısından son derece önemlidir (Hallinger ve Leithwood, 1996). Güçlü bir örgüt kültürüyle, başarılı bir eğitim yönetiminin yapılandırılması ve olumlu sonuçların elde edilebilmesi arasında önemli bir ilişki vardır (Dimmock ve Walker, 1997). Güçlü bir örgüt kültürünün bulunduğu okullarda insan kaynağına önem ve değer verilir, kurumda çalışanların tamamına kurumsal destek sağlanır (Carpenter, 2015); olumlu ve yapıcı bir iletişim ortamı vardır, sorun çözme kapasitesi yüksektir ve çatışmalarda hoşgörü söz konusudur (Buch ve Rivers, 2001). Bu tip okullarda; güçlü, pozitif ve adaletli bir yönetimle birlikte, değişim ve yeniliğe karş1 pozitif bir yaklaşım vardır (Berry, 1997); çalışanlar tarafından olumlu kabul edilen ve benimsenen bir kurumsal kimlik bulunur (Gagliardi, 1986); sağlam bir örgütsel yapıyla birlikte, çalışanlar kurumlarına güvenir ve kurumda çalışmaktan mutludurlar (McMaster, 2015). Bu tip okullarda, birlik ve beraberlik içerisinde hareket etmek vardır (Valimaa, 1998); çalışanlar ekstra gayret göstererek kurumlarına daha çok faydalı olmaya çalışırlar (Bogler ve Somech, 2005) ve kurumlarına zarar verebilecek her türlü tutum ve davranıştan kaçınırlar (Beijaard, Verloop ve Vermunt, 2000). Bu tip kurumlarda, sağlıklı bir okul iklimi ile verimli bir eğitim ve öğretim ortamı bulunacağından (Griffith, 1999) dersler faydalı şekilde işlenir, konuların hedef kazanımları en başarılı şekilde elde edilir; öğrenciler, bireysel farklılıklarıyla uyumlu olarak (Gaziel, 1997), özgüveni yüksek şekilde yetişirler (Gruenert, 2005).

Her örgüt kültürünün, o örgütün ve örgüt elemanlarının başarıları üzerinde etkisinin olduğu gibi, okul kültürünün de okuldaki eğitim ve öğretimin başarılı olabilmesinde önemli etkisi bulunmaktadır. Yeşilyurt'a (2009) göre, bir okulun başarısı, o okuldaki bütün bireylerin başarılarının toplamından oluşmaktadır. Bu anlamda, okulların başarısı, burada görev yapan öğretmenlerin öğretim başarısıyla yakından ilgilidir. Dolayısıyla okulların kendine has olan kültürünün, okulların bütün üyelerinin başarıları üzerinde etkili olacağ 1 açiktır. Okuldaki olumlu ve güçlü örgüt kültüründen hareketle; öğretmen ve 
yöneticilerin birbirlerine karşı olumlu tutumları, görev dağılımında adaletin ve öğretmen ile yönetici arasında insancıl anlayışın olması, okul üyelerinin değişime ve yenileşmeye açık olmaları, öğretmenlerin öğretim başarılarını olumlu yönde etkilemektedir. Arifin'in (2015) araştırma sonuçlarına göre, örgüt kültürüyle öğretmenlerin iş tatmini ve performansları arasında pozitif yönde ve anlamlı bir ilişki vardır. Arifin (2015), kurumdaki olumlu ve güçlü örgüt kültürü algısının öğretmenlerin kurumlarına olan güvenine, bağlılığına, kurumda hissedilen çalışma atmosferine olumlu tesir edeceğinden dolayı, öğretmenlerin iş tatminlerinin ve performanslarının yüksek olacağını belirtmektedir. Kılınç'ın (2014), okul kültürü ve öğretmen profesyonelizmi arasındaki ilişkiyi incelediği araştırma sonuçlarına göre, okul kültürü ile öğretmen profesyonelizmi arasında pozitif yönde bir ilişki vardır ve okul kültürü, öğretmen profesyonelizminin yordayıcısıdır. Öğretmenlerin profesyonel davranışlar sergilemeleri, öğrenme ve öğretime uygun daha etkili bir okul ortamının oluşturulması noktasında kritik bir role sahiptir (Cerit, 2013). K1lınç’a (2014) göre, öğretmen profesyonelizmini artırmaya yönelik olarak, öğretmenlerin çabalarının destekleneceği, öğretimi geliştirmeye yönelik iş birlikçi çalışmaların ön plana çıkarılacağı ve olumlu bir iletişim ortamının sağlanacağı okul kültürünün oluşturulması, okulun amaçlarına ulaşılmasında çok önemli bir etkiye sahiptir.

Balcı'ya (2007) göre, okuldaki eğitim yönetimiyle, okulların etkili olabilmesi arasında önemli bağlantılar vardır. Etkili okulların oluşması adına, okulda her öğrencinin öğrenmesine uygun bir iklim ve kültür oluşturulmasıyla birlikte, öğretmenlerin morallerinin yükseltilmesi etkili yöneticinin ve etkin bir eğitim yönetiminin temel hedefleri arasında olmalıdır. Buradan da anlaş1lacağ1 üzere, okuldaki örgüt kültürünün, etkili yönetim ve etkili okulla karş1lıklı ilişkileri mevcuttur. Okuldaki örgüt kültürü hem yönetimden etkilenmekte hem de yönetimi etkilemekte ve neticede etkili okulun oluşmasında temel belirleyicilerden biri olmaktadır (Balc1, 2007). Ayık ve Ada'nın (2009) araştırmasında, yönetici ve öğretmen görüşlerine göre, okullardaki örgüt kültürü ile okulların etkililiği arasında pozitif yönde, yüksek düzeyde bir ilişki vardır ve okul kültürü, "okul etkililiğinin” yordayıcısıdır.

Okullardaki eğitim yönetimini şekillendiren; eğitim yönetiminin yap1sını ve niteliğini belirleyen, etkili okulların oluşmasını sağlayan en önemli kavramların başında örgüt kültürü ve liderlik gelmektedir (Deal ve Peterson, 1990). Örgüt kültürü, okuldaki liderliği etkilemekte ve liderlik tarzının belir- 
lenmesinde kritik bir rol üstlenmektedir. Aynı şekilde okuldaki liderlik, örgüt kültürünü etkilemekte, örgüt kültürün güçlenmesinde veya zayıflamasında belirleyici olmaktadır (Lashway, 2006a, 2006b). Flores (2004) de eğitim yönetiminin başarılı olabilmesinde, eğitim ve öğretim faaliyetlerinin verimliliğinde çok önemli bir rol üstlenen öğretmenlerin, kendilerini geliştirebilmeleri ve okulda yeni öğrenmeleri gerçekleştirebilmelerinde okul kültürünün ve liderliğin çok önemli olduğunu belirtmektedir (Lashway, 2006c). Şahin (2003) de okul merkezli yönetim uygulamalarının önem ve faydasından bahsederken, okul merkezli yönetimin bulunduğu okullarda öğretmenlerin daha verimli, eğitim ve öğretim faaliyetlerinin de daha başarılı olacağını ifade etmektedir. Leithwood, Menzies, Jantzi ve Leithwood (1996), okulun yeniden yapılanmasında, güçlü bir okul kültürü oluşturulmasında ve öğretmenlerin tükenmişliklerinin giderilmesinde dönüşümcü liderliğin önemine dikkat çekerek; güçlü okul kültürü; okulda, başarılı, mutlu ve çalışma ortamından memnun öğretmenlerin bulunmasında dönüşümcü liderliğin kritik bir rol oynadığını belirtmektedir. Benzer şekilde Silins ve Mulford (2004), öğrenen bir organizasyon kültürüne sahip bir okulun öğretmen liderliğini ve öğrenci başarısını olumlu yönde etkileyeceğini belirtmektedir. Coad ve Berry (1998) de öğrenen organizasyon kültürüne sahip örgütlerin oluşmasında dönüşümcü liderliğin kritik bir rolünün olduğunu belirtmektedir.

Eğitim yönetiminde; okul kültürü ile yakın ilişkileri bulunan ve zaman zaman birbirinin yerine de kullanılan "okul iklimi”nin oluşması ve şekillenmesinde okul kültürünün önemli etkileri bulunmaktadır (Anderson, 1982). Okul ikliminin, okul yönetimi, liderlik, iletişim, güven ve bağl1lık başta olmak üzere örgütsel davranış konularıyla yakın ilişkisi bulunmaktadır (Halpin ve Croft, 1963; Griffith, 1999; Lashway, 2006d). Sağlıklı okul iklimi eğitim ve öğretimin verimli olmasına, öğrencilerin başarılı sonuçlar elde etmesine (Haynes, Emmons ve Ben-Avie, 1997), okuldaki düzensizliklerin giderilmesine (Gottfredson, Gottfredson, Payne ve Gottfredson, 2005; Welsh, 2000) katk1 vermektedir. Grayson ve Alvarez'e (2008) göre, öğretmenlerin tükenmişlik duygularından kurtulmalarında ve işlerini severek yapmalarında okul iklimi önemli bir etkendir. Aynı şekilde Tschannen-Moran, Parish ve DiPaola (2006) da okuldaki olumlu ilişkilerin geliştirilmesinde ve öğrenci başarısında okuldaki iklimin kritik bir rolünün olduğunu belirtmektedir. Özdemir'in (2012) araştırma sonuçlarına göre de okul kültürüyle, okul sağlığı arasında pozitif yönde anlamlı bir ilişki vardır ve okul kültürü okul sağlığının yordayıcısıdır. Sağlıklı bir okul ikliminin oluşması, verimli bir eğitim ve öğretim 
için son derece gerekli bir konudur ve başarılı bir eğitim yönetiminin en önemli hedeflerinden biri de sağlıklı okul ikliminin eğitim kurumlarında tesis edilebilmesidir. Özdemir'e (2012) göre, kurumdaki örgüt kültürünün bilinmesi ve doğru şekilde tespit edilmesi; çalışanların davranışlarının nasıl etkilendiğini görmek açısından gereklidir. Bu durum açık sistem özelliği göstermesi gereken okullar açısından da geçerlidir. Bu nedenle, okul kültürünün farklı boyutlarının, farklı örgütsel özelliklerle ilişkilendirilerek daha iyi anlaş1ması gerekmektedir. Bu durum eğitim yönetiminin sağlıklı şekilde yerine getirilebilmesi açısından oldukça önemlidir.

Eğitim yönetimi alanında yapılan birçok araştırma; okul kültürü ve liderlik arasındaki etkileşimi ortaya koymaktadır. Şahin'in (2011a) araştırma sonuçlarına göre; okul örgütlerine özgü olan öğretimsel liderliğin okul kültürü üzerinde önemli etkileri bulunmaktadır. Okul yöneticilerinin öğretimsel liderlik vasıflarını tam olarak yerine getirmeleri; okulların etkililiği ve öğrenci başarısında önemli bir yeri olan okul kültürünün istenen düzeye gelmesinde önemli katkılar sağlayacaktır. Zembat, Özdemir-Adak, Türker, Beceren-Özdemir ve Biber'in (2011) araştırma sonuçlarına göre okul yöneticilerinin liderlik stilleri ile okul kültürü arasında pozitif yönde, yüksek düzeyde bir ilişki vardır ve liderlik stilleri okul kültürünün yordayıcısıdır. Okul müdürlerinin liderlik ve yönetim becerileri okullardaki eğitim yönetiminin sağlıklı şekilde yapılmasına imkân tanıyan olumlu örgüt kültürünün oluşmasına katk1 sağlamaktadır. Aynı şekilde olumlu ve güçlü örgüt kültürü; liderlik stillerinin olumlu yönde gelişmesine imkân tanımaktadır. Koşar ve Çalık'ın (2011) araştırma sonuçlarına göre, okul yöneticilerinin kullandıkları güç stilleri ile okuldaki örgüt kültürü arasında olumlu yönde ilişkiler vardır.

Organizasyonların başarılı olmaları, önemli oranda örgüt üyelerini birbirine bağlayan ve bir arada tutan; onlara canlılık ve yeni bir ruh aşılayan örgütsel kültüre bağlıdır (Bozoğlu, 2011). Her kurum, verimli ve başarılı olabilme adına, çalışanların kurumla ve çalışma arkadaşlarıyla tam bütünleşmesini (Farh, Podsakoff ve Organ, 1990), ekip ruhuyla hareket ederek takım olarak çalışmasını istemekte (Tansky, 1993), çalışanlarından maksimum oranda üretim ve hizmet beklemekte, görevlerinin ötesinde kuruma katk1 sunmasını, fedakârlık yaparak ekstra çalışma ve gayret sarf etmesini talep etmektedir (Niehoff ve Moorman, 1993). Bireylerin gönüllü, istekli ve fedakârca çalışmalarının kurumdaki birlik ve beraberliği destekleyeceği, bu durumun da kurumdaki verimliliği artıracağı belirtilmektedir. Birçok araş- 
tırmada, resmi ve yazılı görevlerin ötesinde ekstra gayret ve çabaların, kurumların verimliliğinde ve başarısında çok önemli bir rolünün olduğuna işaret edilmektedir (Moorman, Niehoff ve Organ, 1993). Kurumların verimli ve başarılı olabilmelerinde çalışanlar açısından hayatî öneme sahip olan tüm bu özelliklerin toplamı, örgütsel vatandaşlık kavramıla ifade edilmektedir (Podsakoff, Whiting, Podsakoff ve Blume, 2009). Çalışanlar arasındaki uyumun yüksek olması, liderlerin ve yöneticilerin örgütsel vatandaşlık davranışı uygulamalarına destek vermesi, çalışanların ise bu davranışları yerine getirdiklerinde işlerinde daha yüksek bir tatmin sağlayabileceklerini düşünmesi, örgütsel vatandaşlık davranışının uygulanmasını kolaylaştıracaktır (Konovsky ve Organ, 1996). Örgütsel vatandaşlık davranışlarının bulunduğu kurumlarda, başarı ve verimlilikten söz edilebilirken; örgütsel vatandaşl1k davranışlarının bulunmadığı kurumlarda ise çalışma ve üretim konusunda isteksizlik, emek ve fedakârlık noktasında ise eksiklik vardır (Wanger ve Rush, 2000). Bu durum da başarı ve verimliliği olumsuz şekilde etkilemekte, örgütün hedeflerine doğru ilerlemesine engel olmaktadır. Böylesi bir çalışma ortamı ise üretilen mal ve hizmetler konusunda memnuniyetsizliğe neden olmakta ve kurumların hayatta kalabilmelerini imkânsız hale getirmektedir (Konovsky ve Pugh, 1994). Kurumların başarılarında bu denli önemli olan örgütsel vatandaşlık davranışlarının oluşabilmesinde temel belirleyicilerden biri, kurumların sahip oldukları örgüt kültürünün yapısı ve niteliğidir (Moorman ve Blakely, 1995). Örgütsel vatandaşlık davranışlarıyla zıt yöndeki davranışlar olarak nitelendirilebilen, çalışanların örgüte yönelik geliştirdikleri negatif tutumlar olarak tarif edilebilen "örgütsel sinizm" (Abraham, 2000) ile güçlü örgüt kültürü arasında ise negatif yönde bir ilişki vardır (Anderson ve Bateman, 1997). Olumlu ve güçlü örgüt kültürünün bulunduğu kurumlarda örgütsel sinizm az olmakta veya hiç bulunmamaktadır (Balay, Kaya ve Cülha, 2013).

Yaptığı araştırma sonuçlarından hareketle, okullarda örgütsel vatandaşlık davranışlarının geliştirilmesinde, hizmetkâr liderlik ve örgütsel adaletin katkısıyla oluşturulacak okul yapı ve atmosferinin, diğer bir ifadeyle okul kültürünün önemli bir rolünün olduğuna dikkat çeken Akyüz (2012), örgütsel vatandaşlık davranışlarını okullar açısından önemli kılan diğer bir boyutun da öğretmenlerin öğrencilere yönelik sergiledikleri ekstra rol davranışları olduğunu ifade etmektedir. Akyüz'e (2012) göre, öğretmenin rol tanımında yer almayan ancak öğretmenlerin büyük bir bölümü tarafindan gönüllü olarak gerçekleştirilen bu ekstra rol davranışlarının öğrenci başarısında, öğrencilerin 
okula ve öğrenmeye ilişkin tutumlarında olumlu kazanımlara sebep olacağ açıktır. Öğretmenlerden beklenen bu olumlu davranışlara da güçlü bir okul kültürünün desteklediği, başarılı bir eğitim yönetimiyle ulaşmak mümkündür.

Sezgin'in (2010) araştırma sonuçlarına göre, okul kültürüyle öğretmenlerin örgütsel bağl1lığ okul kültürü, öğretmenlerin örgütsel bağlılığının yordayıcısıdır. Araştırmada, öğretmenlerin örgütsel bağlılığının oluşmasında kurumdaki olumlu ve güçlü bir örgüt kültürü varlığının önemli bir etken olduğu belirtilmektedir. Bununla birlikte Sezgin (2010), okulda katı kural ve aşırı bir otorite algısının da öğretmenlerin duygusal bağlılığına zarar verebileceğini ve bağlılığın sadece yüzeysel bir anlam taşıma riskinin bulunabileceğine de dikkat çekmektedir. Aynı şekilde Çetin, Şeşen ve Basım (2012), Erkmen ve Bozkurt (2011), Polat ve Meyda (2011), Erdem (2007) de örgüt kültürüyle örgütsel bağl1lık arasında önemli ilişkilerin bulunduğunu belirtmektedir.

Karataş'ın (2009) yaptığı araştırma sonuçlarına göre, yöneticiler hangi değerleri önemsiyorsa, o kurumda buna benzer bir örgüt kültürünün oluştuğu gözlenmektedir. Fırat'ın (2007) araştırma sonuçlarına göre, okul kültürü ile okul müdürlerinin ve öğretmenlerin değer sistemleri arasında anlamlı ilişkiler vardır; okul kültürü, çalışanların değer sistemlerinin oluşmasında temel belirleyicilerden biridir. Güçlü kültüre sahip okullar, özerkliğe, girişimciliğe yeniliğe ve yaratıcı fikirler ile ekip çalışması değerlerine önem verirler, çal1şanlarını risk almaları konusunda cesaretlendirirler. Bu durum, okul kültürünün güçlü hale gelmesini sağlayan önemli değişkenler arasındadır. Yüksel'in (2009) araştırma sonuçlarına göre, okullardaki örgüt kültürü ile örgütsel güven arasında pozitif yönde anlamlı bir ilişki vardır. Olumlu ve güçlü örgüt kültürü algısı arttıkça, öğretmenlerin okullarına karşı hissettikleri güven duygusu da artmaktadır. Şirin'in (2011) araştırma sonuçlarına göre, öğretmenlerin okul kültürü ile örgütsel sinizm algıları arasında negatif yönde anlamlı bir ilişki saptanmıştır. Okullarda algılanan güçlü ve olumlu kültür arttıkça öğretmenlerin okullarına yönelik olumsuz tutumları azalmaktadır.

Demirtaş'ın (2010a), araştırma bulgularına göre, okul kültürüyle öğrenci başarısı arasında pozitif yönde ve anlamlı bir ilişki vardır. Öğretmenin kişisel ve meslekî anlamda kendisini sürekli geliştirmesi öğrenci başarısını da beraberinde getirmektedir. Dünyadaki ve kendi alanlarındaki gelişmeleri takip eden, sürekli olarak araştıran, sahip olduğu birikimi öğrencileriyle paylaşan öğretmenler öğrencilerinin akademik başarısı üzerinde önemli bir etki oluş- 
tururlar. Bir diğer araştırmasında Demirtaş (2010b), örgütsel bağlılığı yüksek olan öğretmenlerin işlerine ve öğrencilerine daha fazla bağlanarak, öğrencilerinin akademik başarıları için daha çok çaba sarf edeceklerini belirtmektedir. Bu anlamda okuldaki egemen olan kültürün, okuldaki çalışan herkesin ve öğrencilerin davranışlarına etki edeceğini belirten Demirtaş (2010b), okulda çalışanların örgütsel bağl1lık çerçevesinde iş ve görevlerini yapabilmesi için okulda güçlü bir örgüt kültürüne ihtiyacın olduğunu belirtmektedir. Aynı şekilde Stolp ve Smith (1995) de olumlu ve güçlü bir örgüt kültürünün bulunduğu okullarda, mesleklerine bağlı, kendilerini okullarına ve öğrencilerine adamış öğretmenler ile motivasyon ve akademik başarısı yüksek öğrencilerin bulunacağını ifade etmektedir.

Alanyazında, az sayıda da olsa, örgüt kültürüyle başarılı okul arasında bağlantının bulunmadığını ortaya koyan bazı araştırmalar mevcuttur. Negiş-Işık ve Gürsel'in (2013), "Başarılı bir ilköğretim okulunda örgüt kültürü: Etnografik bir durum çalışması" isimli araştırmasında, başarılı bir ilköğretim okulunda var olan örgüt kültürü ayrıntılarıyla betimlenmeye çalışılmıştır. Araştırma sonuçlarına göre katılımcılar; okul başarısında okul kaynaklı değişkenlerden ziyade öğrenci ile ilgili değişkenlerin önemli rol oynadığını belirtmişlerdir. Öğrencilerin çoğunun eğitimli, sosyo-ekonomik olarak üst düzey ailelere mensup oldukları, bu durumun da okul başarısında önemli bir rol oynadığı ifade edilmiştir. Okul başarısının kaynağı olarak ayrıca sınava yönelik yapılan çalışmalara değinilmiş, okul içinde yapılan deneme sınavları özellikle vurgulanmıştır. Negis-Işık ve Gürsel (2013), katılımcılardan elde edilen bu verilerden hareketle, okulun sahip olduğu kültürün okul başarısında rol oynamadığı düşünülebilir şeklinde bir çıkarımda bulunmuştur.

\section{Sonuç ve Öneriler}

Örgüt kültürü, bütün kurumlar başta olmak üzere eğitim kurumları için de çok önemli bir kavramdır. Kurumların hedeflerine ulaşabilmelerinde, başarılı veya başarısız olmalarında örgüt kültürü kritik bir rol oynamaktadır. Böylesine önemli bir faktörün, kavramsal çerçevesinin analiz edilmesi ve etkileşim içinde olduğu faktörlerle ilişkisinin ortaya konulması kurumların başarısı adına oldukça önemlidir.

Kuram ve uygulama alanında yapılan çalışmalardan anlaşılacağı üzere; eğitim yönetiminin en temel konularından olan liderlik, okul iklimi, etkili okul, öğrenen okul, örgütsel vatandaşl1k davranışları, örgütsel güven, örgütsel bağl1l1k, örgütsel sinizm ve öğrenci başarısı başta olmak üzere, eğitim yöne- 
timi alanını ilgilendiren birçok konu ile okul kültürü arasında önemli ilişkiler bulunmaktadır.

Olumlu ve güçlü okul kültürü; eğitim ve öğretimin sağlıklı ve başarılı şekilde yapılmasını, liderliği, okuldaki çalışma ortamını, çalışanların okulu ve öğrencileri sevmesini, güven ve bağlllık duygularıyla görevlerini yerine getirmelerini, ekstra çaba sarf etmelerini ve öğrenci başarısını olumlu yönde etkilemektedir. Bununla birlikte olumlu ve güçlü örgüt kültürü; olumsuz çalışma ortamına neden olan koşulları ortadan kaldırmakta, çalışanların okula karşı negatif duygular beslemesini engellemekte, okuldaki şiddet ve olumsuz olayların önüne geçmekte ve başarısız bir yönetimin oluşmasına müsaade etmemektedir.

Bütün bu sonuçlardan hareketle şu önerilerde bulunulabilir:

Okullarda olumlu ve güçlü örgüt kültürünün artırılması için gerekli çalışmalar yapılmalı ve bu konuya özellikle önem verilmelidir. Bu noktada eğitim yönetiminin en üst kademesinden en alt yönetim birimine kadar, okullardaki olumlu ve güçlü örgüt kültürünün nasıl tesis edilebileceği ve sürdürülebilir bir yapılanmayla bunun devamlılığının sağlanabileceği konusunda araştırmalar yapılmalıdır.

Okullarda güçlü örgüt kültürünün tesisi ve sürdürebilir bir yapıda olması büyük ölçüde okul yönetiminin başarısıyla yakından ilgilidir. Bu noktada özellikle okul müdürleri sahip oldukları bu kritik rolün farkında olmalı ve bunun bilincinde olarak yönetimlerini yapılandırmalıdırlar. Aynı şekilde ilçe millî eğitim müdürleri de bu konuya gerektiği şekilde önem vermeli ve bulundukları ilçedeki bütün okullarda güçlü okul kültürünün oluşması adına ihtiyaç duyulan çalışmaları yapmalıdır. Bu bağlamda ilçe bazında toplantılar yaparak, bilgi ve tecrübe paylaşımlarına önem vermeli; bire bir olarak okulları takip ederek gerekli yönetimsel desteği vermelidir.

Gerek yurt dışında gerekse de yurt içinde güçlü örgüt kültürüne sahip okullar incelenerek, yeni modeller geliştirilmeli, bu modellerin farklı bölge ve şehirlerdeki okullara nasıl uygulanabileceği konusunda çalışmalar yapılmalidır.

Eğitim yönetimi alanında, okul kültürüyle ilgili önemli araştırmaların yapıldığı görülmektedir. $\mathrm{Bu}$ araştırmalar genellikle ana akım çalışmaları paralelinde yürüdügü göze çarpmaktadır. Bu noktada özellikle okul kültürü ile 
ilgili daha çok nitel ve etnografik çalışmalara ayrıca okul kültürü ve eğitim reformu ilişkisini ortaya koyacak araştırmalara da yer verilmesi gerektiği tespiti yapılabilir.

Bütün bu önerilerle birlikte şu konuya da özelikle dikkat çekilmelidir: Yapılan kuram ve uygulama alanındaki çalışmalara göre, güçlü okul kültürü eğitim yönetiminin tüm paydaşlarını olumlu yönde etkilemektedir. Yurt içinde yapılan birçok araştırma sonucuna göre, ülkemizde okul kültürü genel anlamda olumlu ve güçlüdür. Peki böylesi bir durumda okullarda yaşanan; yönetim, uygulama, başarı ve disiplin başta olmak üzere birçok konuyla ilgili sorun nasıl açıklanabilir? Bu ve benzeri sorunlar bağlamında okul kültürü ve eğitim yönetimi ilişkisiyle ilgili araştırmalar derinleştirilmeli; elde edilecek somut, uygulamaya dönük önerilerle güçlü okul kültürünün etki ve faydası artırılmaya çalışılmalıdır.

\section{Kaynakça}

Abraham, R. (2000). Organizatinol cynicism: Base and consequences. Generic, Social and General Psychology Monographs, 126(3), 269-292.

Ada, Ş. ve Ayık, A. (2008). İlköğretim okullarında okul kültürü. The Journal of SAU Education Faculty, 16, 26-39.

Aidla, A. ve Vadi, M. (2007). Relationships between organizational culture and performance in Estonian schools with regard to their size. Baltic Journal of Economics, 7(1), 3-17.

Akyüz, B. (2012). Hizmetkâr liderlik davranışlarının örgütsel adalet, örgütsel vatandaşlık davranışlarl ve performans üzerine etkisi: Eğitim sektörü üzerine bir araştırma. Yayımlanmamış doktora tezi, Gebze Yüksek Teknoloji Enstitüsü, Sosyal Bilimler Enstitüsü.

Allaire, Y. ve Firsirotu, E. M. (1984). Therios of organizational culture. Organizational Studies, 5(3), 193-226.

Anderson, C. S. (1982). The search for school climate: A review of the research. Review of Educational Research, 52(3), 368-420. 
Anderson, L. M. ve Bateman, T. S. (1997). Cynicism in the workplace: Some causes and effects. The Journal of Organizational Behavior, 18, 449-470.

Arifin, H. M. (2015). The influence of competence, motivation and organisational culture to high school teacher job satisfaction and performance. International Education Studies, 8(1), 38-45.

Arl1, D. (2011). Öğretmenlerin örgütsel vatandaşlık davranışlarının örgüt kültürü algılarl ve örgütsel güven düzeyleri açısından incelenmesi. Yayımlanmamış doktora tezi, Ege Üniversitesi.

Arslan, H., Kuru, M. ve Satıcı, A. (2005). İlköğretim ve ortaöğretim okullarındaki örgüt kültürünün karşılaştırılması. Kuram ve Uygulamada Eğitim Yönetimi, 44, 449-472.

Arslan, H., Satıcı, A. ve Kuru, M. (2007). Resmi ve özel ilköğretim okullarının kültür ve etkililik düzeylerinin karşılaştırılması. Kuram ve Uygulamada Ĕ̈itim Yönetimi, 51, 371-394.

Arslan, M., Özer, N. ve Bakır-Ağaoğlu, A. (2009). Administrators' and teachers' views on school culture: A qualitative study. İlkögretim Online, 8(1), 268-281.

Atay, K. (2001). Öğretmen yönetici ve denetmenlerin bakış açısından okul kültürü ve öğretmen verimliliğine etkisi. Kuram ve Uygulamada Eğitim Yönetimi, 25, 179-194.

Avc1, A. (2016). Öğretmen algılarına göre örgüt kültürü. Ö. K. Tüfekçi, (Ed.), Sosyal bilimlerde stratejik araştırmalar içinde (43-57). Germany: Lap Lambert Academic Publishing.

Ayık, A. ve Ada, Ş. (2009). İlköğretim okullarında okul kültürü ile okulların etkililiği arasındaki ilişki. Gaziantep Üniversitesi Sosyal Bilimler Dergisi, 8(2), 429-446.

Ayık, A. ve Şayir, G. (2015). Öğretmenlerin algılarına göre öğrenen örgüt ve okul kültürü arasındaki ilişkinin incelenmesi. İlköğretim Online, 14(2), 379-394. 
Bakioğlu, A. ve Kurnaz, Ö. (2011). Araşttrmada kalite. İstanbul: Nobel Yayınları.

Balay, R., Kaya, A. ve Cülha, A. (2013). Örgüt kültürü ve örgütsel sinizm ilişkisi. C.Ü. Íktisadi ve İdari Bilimler Dergisi, 14(2), 123-145.

Balc1, A. (2007). Etkili okul geliştirme: Kuram, uygulama ve araştırma (4. baskı). Ankara: Pegem A. Yayınları.

Barley, R. S. (1983). Semiotics and the study of occupational and organizational cultures. Administrative Science Quarterly, 28, 393-413.

Bass, B. M. ve Avolio, B. J. (1993). Transformational leadership and organizational culture. Public Administration Quarterly, 17, 112-121.

Başaran, İ. E. (1982). Örgütsel davranışın yöntemi. Ankara: Ankara Üniversitesi Eğitim Fakültesi Yayınları.

Beijaard, D., Verloop, N. ve Vermunt, J. D. (2000). Teachers' perceptions of professional identity: An exploratory study from a personal knowledge perspective. Teaching and Teacher Education, 16, 749-764.

Berry, G. (1997). Leadership and develop of quality culture in schools. International Journal of Educational Management, 2(2), 52-64.

Bipath, K. ve Adeyemo, K. S. (2014). The strength of organizational culture: Organisational performance in South African Schools. Mediterran Journal of Social Sciences, 5(23), 2405-2412.

Bogler, R. (2001). The influence of leadership style on teacher job satisfaction. Educational Administration Quarterly, 37(5), 662-683.

Bogler, R. ve Somech, A. (2005). Organizational citizenship behavior in school: How does it relate to participation in decision making? Journal of Educational Administration, 43(5), 420-438.

Boone, L. E. ve Kurtz, D. L. (2013). Çağdaş işletme (14. baskı). (A. Yalçın, Çev. Ed.). Ankara: Nobel Yayınları. (Orijinal çalışma basım tarihi 2011) 
Bozoğlu, G. (2011). Örgüt kültürü ve örgütsel băğlllk açısından eğitim sektöründe Yalova ilinde karşılaştırmalı bir araştırma. Yayımlanmamış yüksek lisans tezi, Yalova Üniversitesi.

Buch, K. ve Rivers, D. (2001). TQN: The role of leadership and Culture. Leadership \& Organization Development Journal, 22(8), 365-371.

Burns, T. ve Carpenter, J. (2008). Organizational citizenship and student achievement. Journal of Cross-Disciplinary Perspectives in Education, $1(1), 51-58$.

Bursalığlu, Z. (2010a). Eğitim yönetiminde teori ve uygulama (9. bask1). Ankara: Pegem Yayınları.

Bursalığlu, Z. (2010b). Okul yönetiminde yeni yapı ve davranış (15. bask1). Ankara: Pegem Yayınları.

Cameron K. ve Sarah J. F. (1991). Cultural congruence, strength and type: Relationship to effectiveness. Research in Organizational Change and Development, 5, 23-58.

Carpenter, D. (2015). School culture and leadership of professional learning communities. International Journal of Educational Management, 29(5), 682-694.

Cerit, Y. (2013). Okulun bürokratik yapısı ile sınıf öğretmenlerinin profesyonel davranışları arasındaki ilişki. Kuram ve Uygulamada Eğitim Yönetimi, 18(4), 497-521.

Coad, A. F. ve Berry, A. J. (1998). Transformational leadership and learning orientation. The Leadership \& Organization Development Journal, 19(3), 164-172.

Çelik, V. (2009). Okul kültürü ve yönetimi (4. bask1). Ankara: Pegem Yayınlar1.

Çelik, V. (2013). Eğitimsel liderlik (7. baskı). Ankara: Pegem A. Yayınları. 
Çetin, F., Şeşen, H. ve Basım, H. N. (2012). Örgüt kültürünün rol ötesi olumlu davranışlara olan etkisi: Örgütsel bağlılığın aracı değişken rolü. Doğuş Üniversitesi, 13(2), 197-211.

Çetin-Ölçüm, M. (1999). Okul yöneticileri ve öğretmenlere göre örgüt kültürü. M. Ü. Atatürk Eğitim Fakültesi Eğitim Bilimleri Dergisi, 11, 247-264.

Deal, T. E. ve Kenedy, A. A. (1982). Corporate cultures: The rights and rituals of corporate life. Reading, MA: Addison-Wesley.

Deal, T. E. ve Kennedy, A. A. (1983). Culture and school performance. Education Leadership, 40(5), 140-141.

Deal, T. E. ve Peterson, K. D. (1990). The principal's role in shaping school culture. Washington DC: Superintendent of Documents, U.S. Government Printing Office.

Demirkol, A. Y. ve Savaş, A. C. (2012). Okul müdürlerinin örgüt kültürü algilarının incelenmesi. SDÜ Fen Edebiyat Fakültesi Sosyal Bilimler Dergisi, 25, 259-272.

Demirtaş, Z. (2010a). Liselerde okul kültürü ile öğrenci başarısı arasındaki ilişki. Mustafa Kemal Üniversitesi Sosyal Bilimler Enstitüsü Dergisi, 7(13), 208-223.

Demirtaş, Z. (2010b). Okul kültürü ile öğrenci başarısı arasındaki ilişki. Eğitim ve Bilim, 35(158), 3-13.

Deshpande, R. ve Webster, F. E. (1989). Organizational culture and marketing: Defining the research agenda. Journal of Marketing, 53, 3-15.

Dimmock, C. ve Walker, A. (1997). Towards comparative educational administration: Building the case for a cross- cultural school based approach. Comparative Educational Administration, 36(4), 379-401.

DiPaola, M. F. ve Tschannen-Moran, M. (2001). Organizational citizenship behavior in schools and its relationship to school climate. Journal of School Leadership, 11(5), 424-447. 
DiPaola, M. F. ve Hoy, W. K. (2005). Organizational citizenship of faculty and achievement of high school students. The High School Journal, 88(3), $35-44$.

Donmoyer, R. (1999). The continuing quest for a knowledge base: 1976-1998. J. Murphy ve K. S. Louis (Ed.), Handbook of research in educational administration içinde (25-43). San Francisco: Jossey-Bass.

Drucker, P. F. (2011). Büyük değişimler çă̆ında yönetim. (Z. Dicleli, Çev.). İstanbul: Optimist Yayınları. (Orijinal çalışma basım tarihi 2009)

Drucker, P. F. (1988). The coming of the new organization. Harvard Business Review, Ocak-Şubat, 28, 45-53.

Drucker, P. F. (2013). Etkin yöneticiyi etkin yapan nedir? D. Goleman ve diğ., Liderlik: Harvard Business Review'den en kalıcı yönetim fikirleri içinde (35-52). (M. İnan, Çev.). İstanbul: Optimist Yayınları. (Orijinal çalışma basım tarihi 2011)

Dumay, X. (2009). Origins and consequences of shools' organizational culture for student achievement. Educational Administration Quarterly, 45(4), 523-555.

Edmonds, R. (1979). Effective schools for the urban poor. Educational Leadership, 37(1), 15-24.

Ellett, C. D. ve Teddlie, C. (2003). Teacher evaluation, teacher effectiveness and school effectiveness: Perspectives from the USA. Journal of Personel Evaluation in Education. 17(1), 101-128.

Erdem, R. (2007). Örgüt kültürü tipleri ile örgütsel bağlılık arasındaki ilişki: Elazığ il merkezindeki hastaneler üzerinde bir çalışma. Eskişehir Osmangazi Üniversitesi İ̈BF Dergisi, 2(2), 63-79.

Erkmen, T. ve Bozkurt, S. (2011). Örgüt kültürü ve örgütsel bağlllık ilişkisinin incelenmesine yönelik bir araştırma. Marmara Üniversitesi İI.I.B.F. Dergisi, 30, 197-228. 
Evers, C. (2003). Philosophical reflections on science in educational administration. International Studies in Educational Administration, 31(3), $30-41$.

Farh, J. L., Podsakoff, P. M. ve Organ, D. W. (1990). Accounting for organizational citizenship behavior: Leader fairness and task scope versus satisfaction. Journal of Management, 16(4), 705-721.

Fırat, N. (2007). Okul kültürü ve ögrretmenlerin değer sistemleri. Yayımlanmamış doktora tezi, Dokuz Eylül Üniversitesi.

Flores, M. A. (2004). The impact of school culture and leadership on new teachers' learning in the workplace. International Journal of Leadership in Education: Theory and Pratice, 7(4), 297-318.

Fyans, L. J. ve Maehr. M. L. (1990). School culture, student ethnicity, and motivation. Urbana, Illinois: The National Center for School Leadership (Eric Number: ED 327 947).

Gagliardi, P. (1986). The creation and change of organizational cultures: A conceptual framework. Organizational Studies, 7(2), 117-134.

Gaziel, H. H. (1997). Impact of school culture on effectiveness of secondary schools with disadvantaged students. The Journal of Educational Research, 90(5), 310-318.

Gedikoğlu, T. (1997). Eğitim yönetimi, dün, bugün ve 2000'li y1llara doğru. Eğitim Yönetimi, 3(3), 299-308.

Goldring, L. (2002). The power of school culture. Leadership, 32, 32-55. (ERIC Document Reproduction Servise No: EJ659104).

Gottfredson, G. D., Gottfredson, D. C., Payne, A. A. ve Gottfredson, N. C. (2005). School climate predictors of school disorder: Results from a national study of delinquency prevention in schools. Journal of Research in Crime and Delinquency, 42(4), 511-532. 
Grayson, J. L. ve Alvarez, H. K. (2008). School climate factors relating to teacher burnout: A mediator model. Teacher and Teacher Education, 24, 1349-1363

Griffith, J. (1999). The school leadership, school climate relation: Identification of school configurations associated with change in principals. Educational Management and Administration, 28(3), 317-338.

Gruenert, S. (2005). Correlations of collaborative school cultures with student achievement. NASSP Bulletin, 89, 43-55.

Gün, B. ve Çağlayan, E. (2013). Implications from the diagnosis of a school culture at a higher education institution. Turkish Online Journal of Qualitative Inquiry, 4(1), 47-59

Hackman, P. E. (1993) School restructuring in practice. Reckoning with the culture of school. International Journal of Educational Reform, 2(3), 263-271.

Hallinger, P. ve Leithvrood K. (1996). Culture and educational administration: A case of finding out what you don't know you don't know. Journal of Educational Administration, 34(5), 98-116.

Halpin, A. W. ve Croft, D. B. (1963). The organizationl climate of schools. Chiago: Midwest Administration Center of the University of Chicago.

Hanushek, E. A. (1997). Assesing the effects of school resources on student performance. Educational Evaluation and Policy Analysis, 19(2), 141-169.

Harrison, R. (1972). Understanding your organization's character. Harvard Business Review, 50(23), 119-128.

Haynes, N. M., Emmons, C. ve Ben-Avie, M. (1997). School climate as a factor in student adjustment and achievement. Journal of Educational and Psychological Consultation, 8(3), 321-329. 
Herndon, B. C. (2007). An analysis of the relationships between servant leadership, school culture, and student achievement. Yayımlanmamış doktora tezi. University of Missouri, Columbia.

Hodgetts, R. M. (1997). Yönetim: Teori, süreç ve uygulama (Çetin, C. ve Can Mutlu, E., Çev.). İstanbul: Der Yayınları. (Orijinal çalışma basım tarihi 1990)

Hofstede, G. (1998). Attitudes, values and organizational culture: Disentangling the concepts. Organization Studies, 19(3), 477-492.

Hofstede, G. (2011). Dimensionalizing cultures: The hofstede model in context. Online Readings in Psychology and Culture, 2(1), 1-26.

Hofstede. G., Neuijen, B., Ohayv, D. D. ve Sanders, G. (1990). Measuring organizational cultures: A qualitative and quantitative study across twenty cases. Administrative Science Quarterly, 35, 286-316.

Hoy, W. K. ve Miskel C. G. (2010). Eğitim yönetimi: Teori, araştırma ve uygulama (S. Turan, Çev. Ed.). Ankara: Nobel Yayınları. (Orijinal çalışma basım tarihi 1998)

Ilgar, L. (2005). Eğitim yönetimi, okul yönetimi, sınıf yönetimi (3. baskı). İstanbul: Beta Yayınları.

İpek, C. (2012). Öğretmen algılarına göre ortaöğretim kurumlarında örgütsel kültür ve örgütsel vatandaşlık davranışı. Kuram ve Uygulamada Ĕgitim Yönetimi, 18(3), 399-434.

İra, N. (2011). Eğitim fakültelerinde örgütsel kültür ve yönetsel etkililik. Yayımlanmamış doktora tezi, Dokuz Eylül Üniversitesi.

Kalkan, A. (2013). Algllanan örgüt kültürünün, örgütsel vatandaşlık davranışı üzerindeki etkisi: Kuramsal ve görgül bir araştırma. Yayımlanmamış doktora tezi, Selçuk Üniversitesi.

Karasar, N. (2007). Bilimsel araştırma yöntemi (17. baskı). Ankara: Nobel Yayınları. 
Karataş, E. (2009). Ĕ̌itim yönetiminde iş değerleri ve örgüt kültürü. Yayımlanmamış yüksek lisans tezi, Uşak Üniversitesi.

Kılınç, A. Ç. (2014). Öğretmen profesyonelizminin bir yordayıcısı olarak okul kültürü. Eğitim ve Bilim, 39(174), 105-118.

Konovsky, M. A. ve Organ, D. W. (1996). Dispositional and contextual determinants of organizational citizenship behavior. Journal of Organizational Behavior, 16, 215-224.

Konovsky, M. A. ve Pugh, S. D. (1994). Citizenship behavior and social exchange. Academy of Management Journal, 37(3), 656-669.

Korkut, A. ve Hacifazlığlu, Ö. (2011). Öğretmenlerin okul kültürünü algılama düzeyleri: Büyükçekmece örneği. Elektronik Sosyal Bilimler Dergisi, 10(37), 135-152.

Koşar, D. ve Yalçınkaya, M. (2013). Öğretmenlerin örgütsel vatandaşlık davranışlarının yordayıcıları olarak örgüt kültürü ve örgütsel güven. Kuram ve Uygulamada Eğitim Yönetimi, 19(4), 603-627.

Koşar, S. ve Çalık, T. (2011). Okul yöneticilerinin yönetimde gücü kullanma stilleri ile örgüt kültürü arasındaki ilişki. Kuram ve Uygulamada Eğitim Yönetimi, 4, 581-603.

Lashway, L. (2006a). The landscape of school leadership (4. bask1). S. C. Smith ve P. K. Piele, (Ed.), School leadership içinde (18-37). California: Corwin Press A SAGE Publications Company.

Lashway, L. (2006b). The effects of leadership (4. bask1). S. C. Smith ve P. K. Piele, (Ed.), School leadership içinde (38-49). California: Corwin Press A SAGE Publications Company.

Lashway, L. (2006c). Leadership styles and strategies (4. bask1). S. C. Smith ve P. K. Piele, (Ed.), School leadership içinde (77-103). California: Corwin Press A SAGE Publications Company. 
Lashway, L. (2006d). Developing school leader (4. bask1). S. C. Smith ve P. K. Piele, (Ed.), School leadership içinde (105-128). California: Corwin Press A SAGE Publications Company.

Leithwood, K., Menzies, T., Jantzi, D. ve Leithwood, J. (1996). School restructuring, transformational leadership and the amelioration of teacher burnout. Anxiety, Stress and Coping: An International Journal, 9(3), 199-215.

Lim, B. (1995). Examing the organizational culture and organizational performance link. Leadership \& Organizational Development Journal, 16(5), 16-21.

Lok, P. ve Crawford, J. (1999). The relationship between commitment and organizational culture, subculture, leadership style and job satisfaction in organizational change and development. Leadership \& Organizational Development Journal, 20(7), 365-373.

Lunenburg, F. C. ve Ornstein A. C. (2013). Eğitim yönetimi (G. Arastaman, Çev. Ed.). Ankara: Nobel Yayınları. (Orijinal çalışma basım tarihi 2004)

Macneil, A. J., Prater, D. L. ve Bush, S. (2009). The effect of school culture and climate on student achievement. Int. J. Leadership in Education, 12(1), 73-84.

Maxcy, S. J. (2001). Educational leadership and management of knowing: The aesthetics of coherentism. Journal of Educational Administration, 39(6), 573-588.

McMaster, C. (2015). "Where is ?": Culture and the process of change in the development of inclusive schools. International Journal of Whole Schooling, 11(1), 16-34.

Meek, L. V. (1988). Organizational culture: Origins and weaknesses. Organizational Studies, 9(4), 453-473.

Moorman, R. H. ve Blakely, G. L. (1995). Individualism-collectivism as an individual difference predictor of organizational citizenship behavior. Journal of Organizational Behavior, 16, 127-142. 
Moorman, R. H., Niehoff, B. P. ve Organ, D. W. (1993). Treating employees fairly and organizational citizenship behavior: Sorting the effects of job satisfaction, organizational commitment, and procedural justice. Employee Responsibilities and Rights Journal, 6(3), 209-225.

Negiş-Işık, A. ve Gürsel, M. (2013). Organizational culture in a successful primary school: An ethnographic case study. Educational Sciences: Theory \& Practice. 13(1), 221-228.

Niehoff, B. P. ve Moorman, R. H. (1993). Justice as a mediator of the relationship between methods of monitoring and organizational citizenship behavior. Academy of Management Journal, 36, 527-556.

O’Hanlon, J. (1983). Theory Z in school administration? Educational Leadership, 40(5), 16-18.

Ogbonna, E. ve Harris, L. C. (2000). Organizational culture and performance: Empirical evidence from UK companies. International Journal of $\mathrm{Hu}$ man Resource Management, 11(4), 766-788.

Oğuz, E. ve Y1lmaz, K. (2006). İlköğretim okulu öğretmenlerinin okul kültürüne ilişkin algıları (Yozgat örneği). Eğitim ve Bilim, 31(142), 89-98.

Owens, R. G. (2001). Organizational behavior in education: Instructional leadership and school reform. Bostan: Allyn and Bacon.

Owens, R. G. ve Steinhoff, C. R. (1988). Towards a theory of organizational culture. Jounal of Educational Administration, 27(3), 6-16.

Örücü, D. ve Şimşek, H. (2011). Akademisyenlerin gözünden Türkiye'de eğitim yönetiminin akademik durumu: Nitel bir analiz. Kuram ve Uygulamada Eğitim Yönetimi, 17(2), 167-197.

Özdemir, S. (2012). İlköğretim okullarında okul kültürü ile örgütsel sağl1k arasındaki ilişki. Kuram ve Uygulamada Eğitim Yönetimi, 18(4), 599-620. 
Pawlas, G. (1997). Vision and school culture. National Association of Secondary School Principals (NASSP) Bulletin, 81(587), 118-120.

Peters, T. J. ve Waterman, Jr. R. H. (1984). In search of excellence, lessons from America's best-run companies. New York: Warner Books.

Pettigrew, A. M. (1979). On studying organizational cultures. Administrative Science Quarterly, 24(4), 570-581.

Podsakoff, N. P., Whiting, S. W., Podsakoff, P. M. ve Blume B. D. (2009). Individual and organizational level consequences of organizational citizenship behaviors: A meta-analysis. Journal of Applied Psychology, 94(1), 122-141.

Polat, M. ve Meyda, H. C. (2011). Örgüt kültürü bağlamında güç eğilimi ve örgütsel bağl1lık ilişkisinde örgütsel özdeşleşmenin arac1lık rolü. Atatürk Üniversitesi İktisadi ve İdari bilimler Dergisi, 25(1), 153-171.

Pounder, D. G., Ogawa R. T. ve Adams, E. A. (1995). Leadership as an organization - wide phenomena: Its impact on school performance. Educational Administration Ouarterly, 31(4), 564-588.

Robbins, S. P., Decenzo, D. A. ve Coulter, M. (2013). Yönetimin esasları (A. Öğüt, Çev.). Ankara: Nobel Yayınları. (Orijinal çalışma basım tarihi 2007)

Robbins, S. P. ve Judge, T. A. (2012). Örgütsel davranış (14. bask1). (İ. Erdem, Çev.). Ankara: Nobel Yayınları. (Orijinal çalışma basım tarihi 2003)

Salfi, N. A. ve Saeed, M. (2007). Relationship among school size, school culture and students' achievement at secondary level in Pakistan. International Journal of Educational Management, 21(7), 606-620.

Schein, E. H. (1984). Coming to a new awareness of organizational culture. Sloan Management Review, 25(2), 3-16.

Schein, E. H. (1990). Organizational culture. American Psychologist, 45(2), 109-119. 
Schein, E. H. (1996). Three cultures of management: The key to organizational learning. Sloan Managemet Review, 38(11), 9-20.

Schein, E. H. (2004). Organizational culture and leadership. San Francisco: John Wiley \& Sons, Inc.

Scheurich, J. J. (1995). The knowledge base in educational administration: Postpositivist reflections. R. Donmoyer, M. Imber ve J. Scheurich, (Ed.), The knowledge base in educational administration: Multiple perspectives içinde (17-31). Albany: State University of New York Press.

Schneider, B., Ehrhart, M. G. ve Macey, W. H. (2013). Organizational climate and culture. Annual Review of Psychology, 64, 361-388.

Schneider, C. S. (1988). National vs. corporate culture: Implications for human resource management. Human Resource Management, 27(2), 231-246.

Schoen, L. T. ve Teddlie, C. (2008). A new model of culture: A response to call for conceptual clarity. School Effectiveness and School Improvement, 19(2), 129-153.

Sezgin, F. (2010). Öğretmenlerin örgütsel bağl1lı̆̆ının bir yordayıcısı olarak okul kültürü. Eğitim ve Bilim, 35(156), 142-159.

Shaw, J. ve Reyes, P. (1992). School cultures: organizational value orientation and commitment. Journal of Educational Research, 85(5), 295-302.

Silins, H. ve Mulford, B. (2004). Schools as learning organizations-effects on teacher leadership and student outcomes. Schools Effectiveness and Scholl Improvement, 15(3-4), 443-466.

Smircich, L. (1983). Concepts of culture and organizational analysis. Administrative Science Quarterly, 28, 339-358.

Sönmez, M. A. (2006). Meslek liselerinde örgüt kültürü. Kuram ve Uygulamada Ĕ̈itim Yönetimi, 45, 85-108. 
Stolp, S. ve Smith, S. (1995). Transforming school culture: Stories, symbols, values and the leader's role. ERIC Clearinghouse on Education Management, USA: University of Oregon.

Şahin, S. (2003). Okul merkezli yönetim uygulamaları. Kuram ve Uygulamada Eğitim Yönetimi, 36, 582-605.

Şahin, S. (2004). Okul müdürü ve öğretmenler ile okulun bazı özellikleri açısından okul kültürü üzerine bir değerlendirme. Kuram ve Uygulamada Ĕ̈itim Yönetimi, 39, 458-474.

Şahin, S. (2010). Okul kültürünün bazı değişkenler açısından incelenmesi. Elementary Education Online, 9(2), 561-575.

Şahin, S. (2011a). Öğretimsel liderlik ve okul kültürü arasındaki ilişki (İzmir ili örneği). Kuram ve Uygulamada Eğitim Bilimleri (Educational Sciences: Theory\&Practice), 11(4), 1909-1928.

Şahin, S. (2011b). An aspect on the school culture in Turkey and the United States. Asia Pacific Educ. Rev., 12, 593-607.

Şahin-Fırat, N. (2010). Okul müdürü ve öğretmenlerin okul kültürü ile değer sistemlerine ilişkin algıları. Eğitim ve Bilim, 35(156), 71-83.

Şimşek, Y. ve Altınkurt, Y. (2010). Endüstri meslek liselerinde görev yapan öğretmenlerin okul kültürüne ilişkin görüşleri. Milli Eğitim, 187, 372-389.

Şirin, E. (2011). İlköğretim okullarındaki öğretmenlerin okul kültürü algıları ile örgütsel sinizm tutumları arasındaki ilişki (İstanbul ili Esenyurt ilçesi örneği). Yayımlanmamış yüksek lisans tezi, Yeditepe Üniversitesi.

Şişman, M. (2007). Örgütler ve kültürler (2. baskı). Ankara: Pegem Yay.

Şişman, M. (2012). Türk eğitim sistemi ve okul yönetimi (5. bask1). Ankara: Pegem Yay. 
Tansky, J. W. (1993). Justice and organizational citizenship behavior: What is the relationship? Employees Responsibilities and Rights Journal, 6, 195-207.

Taymaz, H. (2009). Okul yönetimi (9. baskı). Ankara: Pegem Yayınları.

Terzi, A. R. (2005). İlköğretim okullarında örgüt kültürü. Kuram ve Uygulamada Eğitim Yönetimi, 43, 423-442.

Tierney W. G. (1988). Organizational culture in higher educational: Defining essentials. Journal of Higher Education, 59, 2-21.

Tschannen-Moran, M., Parish, J. ve DiPaola, M. F. (2006). School climate and state standards: How interpersonal relationships influence student achievement. Journal of School Leadership, 16, 386-415.

Tucker, B. A. ve Russell, R. F. (2004). The influence of the transformational leader. Journal of Leadership and Organizational Studies, 10(4), 103-111.

Valimaa, J. (1998). Culture and identity in higher education research. Higher Education, 36, 119-138.

Wagner, S. L. ve Rush, M. C. (2000). Altruistic organizational citizenship behavior: Context, disposition, and age. The Journal of Sosial Psychology, 140(3), 379-391.

Welsh, W. N. (2000). The effects of school climate on school disorder. The ANNALS of the American Academy of Political and Social Science, 567, 88-107.

Wiener, Y. (1988). Forms of values systems: A focus on organizational effectiveness and cultural change and maintenance. Academy of Management Review, 13, 534-545.

Wilkins, A. L. ve Ouchi, W. G. (1983). Efficient cultures: Exploring the relationship between culture and organizational performance. Administrative Science Quarterly, 28, 468-481. 
Willower, D. J. ve Forsyth, P. B. (1999). A brief history of scholarship in educational administration. J. Murphy ve K. S. Louis, (Ed.), Handbook of research in educational administration içinde (1-23). San Francisco: Jossey-Bass.

Yeşilyurt, E. (2009). Okul kültürünün öğretim başarısına olan etkisine yönelik öğretmen görüşleri (Elazığ ili örneği). Erzincan Eğitim Fakültesi Dergisi, 11(2), 195-214.

Yolcu, H. (2016). Örgüt kültürü ve ilişkili olduğu örgütsel sonuçlar: Kuramsal bir çalışma. Journal of Human Sciences, 13(3), 4501-4519.

Yüksel, F. (2009). Ortaögretim kurumlarında örgüt kültürü ile örgütsel güven arasındaki ilişki. Yayımlanmamış yüksek lisans tezi, Maltepe Üniversitesi.

Zembat, R., Özdemir-Adak, A., Türker, S., Beceren-Özdemir, B. ve Biber, K. (2011). The relationship between preschool administrators' leadership styles and school culture. NWSA Education Sciences, 7(2), 789-811. 